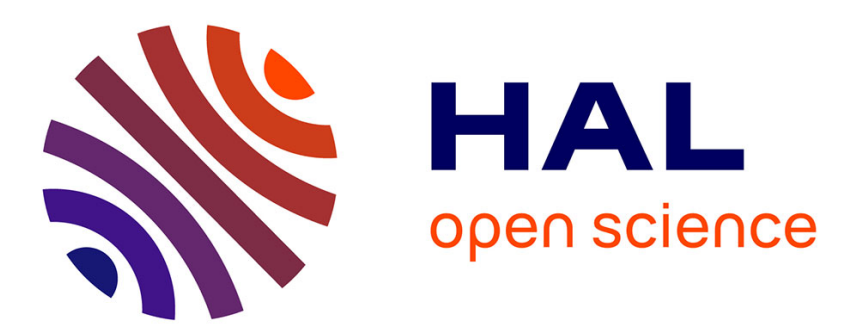

\title{
Spatial variability of metallic and organic contamination of anguilliform fish in New Caledonia
}

Marine J. Briand, Yves Letourneur, Xavier Bonnet, Emmanuel Wafo, Thomas Fauvel, François Brischoux, Gaël Guillou, Paco Bustamante

\section{- To cite this version:}

Marine J. Briand, Yves Letourneur, Xavier Bonnet, Emmanuel Wafo, Thomas Fauvel, et al.. Spatial variability of metallic and organic contamination of anguilliform fish in New Caledonia. Environmental Science and Pollution Research, 2014, 21 (6), pp.4576-4591. 10.1007/s11356-013-2327-0 . hal-00959728

\section{HAL Id: hal-00959728 \\ https://hal.science/hal-00959728}

Submitted on 17 Mar 2014

HAL is a multi-disciplinary open access archive for the deposit and dissemination of scientific research documents, whether they are published or not. The documents may come from teaching and research institutions in France or abroad, or from public or private research centers.
L'archive ouverte pluridisciplinaire HAL, est destinée au dépôt et à la diffusion de documents scientifiques de niveau recherche, publiés ou non, émanant des établissements d'enseignement et de recherche français ou étrangers, des laboratoires publics ou privés. 
Spatial variability of metallic and organic contamination of anguilliform fish in New Caledonia

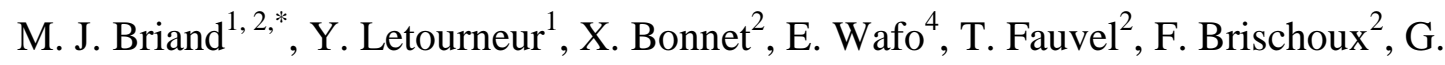
Guillou $^{3}$, P. Bustamante ${ }^{3}$

${ }^{1}$ Université de la Nouvelle-Calédonie, Laboratoire LIVE and LABEX «CORAIL», BP R4, 98851 Nouméa cedex, New Caledonia

${ }^{2}$ Centre d'Etudes Biologiques de Chizé, UPR 1934-CNRS, 79360 Villiers-en-bois, France

${ }^{3}$ Littoral Environnement et Sociétés (LIENSS), UMRi 7266 CNRS-Université La Rochelle, 2 rue Olympe de Gouges, F-17000 La Rochelle, France

${ }^{4}$ Laboratoire de Chimie Analytique, IMBE UMR 7263 CNRS, 237 IRD / UMR S476 UMR A1260, AMU, Marseille

* Corresponding author: Phone: $(+687) 290290$ E-mail: marine.briand@univ-nc.nc 
ABSTRACT: New Caledonia is one of the main hot spots of biodiversity on the planet. Large amounts of contaminants are discharged into the lagoon as a result of increasing anthropogenic activities such as intense mining, urbanization and industrialization. Concentrations of 14 trace elements and 26 persistent organic pollutants (POPs: PCBs and pesticides) were measured in the muscles of two anguilliform fish species, over a coast to barrier reef gradient in two lagoon areas differently exposed to anthropic disturbances. This study emphasizes the high trace element contamination status of anguilliform fish and also highlights slight but perceptible organic pollution. The contamination extends throughout the lagoon, from coast to barrier reef, even in areas remote from emission points. High levels of trace elements, especially those linked to mining activities (i.e. $\mathrm{Co}, \mathrm{Cr}, \mathrm{Fe}, \mathrm{Mn}$ and $\mathrm{Ni}$ ), were detected in coastal sites. Furthermore the large dispersion of most POPs throughout the entire lagoon poses the question of their potential toxicity on marine organisms from numerous habitats. Our results underline the need for long term monitoring of various contaminants over large spatial and time scales.

Keywords: trace elements; PCBs; pesticides; POPs; carnivorous fish; coral reefs; SW Pacific Ocean. 


\section{Introduction}

Coral reefs are threatened by a wide range of natural and anthropic disturbances, including chemical pollution (Richmond, 1993). Three main contaminant classes are particularly involved: polychlorinated biphenyls (PCBs), pesticides (both classes are part of persistent organic pollutants or POPs), and metallic trace elements. These ubiquitous contaminants can be toxic, even at low concentrations; they are resistant to degradation, transported over long distances and can bioaccumulate in marine organisms (e.g. Phillips 1995; Robertson and Hansen 2001). The half-life of contaminants in the marine environment is estimated to be at least a decade for the most persistent PCBs (Sinkkonen and Paasivirta 2000; Robertson and Hansen 2001), several years to a decade for trace elements such as $\mathrm{Hg}$ (Lodenius 1991), and several months to years for pesticides (Hellawell 1988). After their release into the marine environment, some contaminants can be strongly accumulated by organisms of different trophic levels (Van Ael et al. 2012; Dummee et al. 2012).

Southwest Pacific coral reefs are generally in good health. However, for a few decades, toxic wastes released by human activities threaten some of them (Richmond 1993). New Caledonia's lagoon, the largest in the world, is no exception. This hot spot of biodiversity is subjected to increasing contamination pressure resulting from industrialisation and urbanisation. New Caledonia is the third producer of nickel ore in the world (Dalvi et al. 2004). Since the end of the $19^{\text {th }}$ century, many open-cast mines and three metallurgical factories have been opened. Mining activities and natural soil erosion due to rainfall (Ambatsian et al. 1997) generate massive sediment deposits and discharge of associated trace elements ( $\mathrm{Co}, \mathrm{Cr}, \mathrm{Fe}, \mathrm{Mn}$ and $\mathrm{Ni}$,) into the lagoon. Furthermore, with the expansion of industrial factories and urban development, the lack of efficient treatment of wastewater and the use of pesticides for agriculture, the contamination by POPs is also an important issue. Nearly 250 pesticides are officially authorized in New Caledonia (DAVAR, 2001). Twentysix of these are banned but in Europe are still extensively used in NC.

Several studies focused on trace metal contaminants in coastal waters, in particular around Nouméa (the main urban region) (Fernandez et al. 2006; Metian et al. 2008a, b; Hédouin et al. 2008, 2009, 2011). Bioaccumulation of mining (Co, Cr, Fe, Mn and Ni) and urban trace elements ( $\mathrm{Ag}, \mathrm{As}, \mathrm{Cd}, \mathrm{Cu}, \mathrm{Hg}, \mathrm{Pb}, \mathrm{Se}, \mathrm{V}$ and $\mathrm{Zn}$ ) have been investigated in various taxa (crustaceans, molluscs, ascidians) (Bustamante et al. 2000; Hédouin et al. 2006, 2007, 2009, 2010, 2011; Pernice et al. 2009; Metian et al. 2008a, 2010). One study recently 
revealed high contamination levels by trace elements in fish from the south-western lagoon, extending from the coast to the barrier reef (Bonnet et al. 2014). However, there is still little information available about trace element contamination of fish across the whole lagoon in New Caledonia (Chouvelon et al. 2009, Fernandez and Breau 2011; Metian et al. 2013). Furthermore, to our knowledge there is no information available to date on PCB and pesticide concentrations in marine organisms in New Caledonia.

Analyses of spatial patterns of contamination allow the identification of their environmental sources. They also lead to a better understanding of the physical, chemical and biological processes involved in contaminant accumulation (Robertson and Hansen 2001; Johnson et al. 2005). However, with the exception of the coastal region (especially in Nouméa), contamination by trace elements is insufficiently documented and its impact on marine ecosystems remains unclear. Considering the immense surface of the south-western lagoon of New Caledonia, it is necessary to extend investigations to a large spatial scale and to other contaminants such as POPs.

Marine top predators, mainly long-living species, bioaccumulate high levels of metallic elements (e.g. $\mathrm{Cd}$ and $\mathrm{Hg}$ ) or organochlorine pollutants in their tissues (e.g. Adams and McMichael 1999; Wafo et al. 2012). Fish are particularly useful to assess contamination status and distribution of pollutants; especially if they are site-attached or even territorial, living in benthic habitats and have a high trophic level (carnivorous) (e.g. Kojadinovic et al. 2007; Dierking et al. 2009). The sedentary nature of fish is a crucial aspect in spatial variability studies of contamination. Anguilliform fish (morays, congers and snake eels), which are ubiquitous organisms highly represented in tropical marine waters, fulfil the conditions of good bioindicators in contamination monitoring (Bonnet et al. 2014). These sedentary benthic predators, which mainly live in coral reef matrices of shallow waters, are good candidates for studying the impact and spatial variability of contamination in marine environments. Surprisingly, to date they have received little interest, which could be due to their cryptic lifestyle and the difficulty to collect them (Ineich et al. 2007).

In this general context, the main purposes of this study were 1) to determine the level of contamination of two anguilliform fish species by trace elements and POPs, 2) to study the spatial variability of these contaminants along two coast-barrier reef gradients which are differently exposed to human activities. As the influence of ecological and biological factors on the concentration of contaminants is important, three biological parameters (body size, 
trophic position, and lipid content in tissue) and their link to the bioaccumulation processes were also investigated.

\section{Materials and methods}

\subsection{Fish sampling and study areas}

Two anguilliform species were studied, Gymnothorax chilospilus (Muraenidae) and Conger sp. (Congridae). Capture of specimens was carried out using sea kraits (Laticauda spp.) because the prey of these predators is almost exclusively anguilliform fish. This method has been successfully used in previous studies (e.g. Reed et al. 2002; Ineich et al. 2007; Brischoux et al. 2011). The prey items were obtained by a gentle massage of the sea krait abdomen. Because the eels consumed are non-spiny, the snake readily regurgitates their prey (Brischoux and Bonnet 2009) without any effect on their survival (Fauvel et al. 2012). The spatial accuracy of sea snake sampling and their use as sentinels was described in previous studies (Brischoux et al. 2007a, 2009; Brischoux and Bonnet 2008; Bonnet 2012). Sea kraits probe the surrounding seafloors within a radius of $10-15 \mathrm{~km}$ and anguilliform fish are extremely sedentary. Considering the large spatial scale of the current study, this accuracy was sufficient to examine possible local influences along a coast-barrier reef gradient.

The study was realized in the South Western lagoon of New Caledonia. Both fish species were caught in two main areas: Grand Nouméa (GN) and Grand Lagon Sud (GS) (Fig. 1). Grand Nouméa, which is close to the main city of Nouméa, is subject to a variety of anthropic pollution such as industrial activities, farming industries and wastewater. In particular a nickel factory has functioned since 1880 (SLN, Société Le Nickel, Fig. 1). Grand Lagon Sud is less influenced by industrial and urban pollution. Nevertheless, since 1950 mining activity has developed near the Bay of Prony (Goro-Nickel, Vale Inco, Fig. 1), increasing the erosion of lateritic soil in this region. For each area, three stations located on a coast-barrier reef gradient inside the lagoon were sampled: Kuendu beach (coast; CO1), Signal islet (intermediate-reef; IR1) and Amédée islet (barrier-reef; BR1) inside GN and Ouen island (coast; CO2), Mato islet (intermediate-reef; IR2) and N'da islet (barrier-reef; BR2) inside GS (Fig. 1). Sampling was carried out from January to April 2011 and from August to 
September 2011, corresponding respectively to the hot and wet versus cool and dry seasons in New Caledonia.

Each fish was identified, measured and weighed prior to dissection (Table 1). As some fish collected were partially digested, their total length (TL) was estimated applying allometric equations using either the snout vent length, or the tail length (Brischoux et al. 2007b). For each individual of both species, a piece of white muscle was sampled on the nondigested part and immediately frozen at $-30^{\circ} \mathrm{C}$ for subsequent analyses. Muscle tissues were freeze-dried and ground to powder with a porcelain mortar and pestle.

\subsection{Trace element analyses}

The total $\mathrm{Hg}$ concentration in the powder obtained from the tissues was determined by analysing the $\mathrm{Hg}$, with an Advanced Mercury Analyzer (ALTEC AMA 254), directly on aliquots ranging from 5 to $50 \mathrm{mg}$ of dry sample weighed to the nearest $0.01 \mathrm{mg}$ (Bustamante et al. 2006). From 150 to $300 \mathrm{mg}$ of each sample were digested using a 3:1 v:v nitrichydrochloric acid mixture with $65 \%$ ultrapure $\mathrm{HNO}_{3}$ and ultrapure $37 \% \mathrm{HCl}$. The acidic digestion was performed overnight under ambient temperature and then heated in a microwave for $30 \mathrm{~min}$, increasing the temperature up to $105^{\circ} \mathrm{C}$, and $15 \mathrm{~min}$ at $105^{\circ} \mathrm{C}(1200$ W). After the mineralization process, each sample was diluted to 30 or $50 \mathrm{ml}$ with milli-Q quality water, according to the volume of acid added to the mineralization ( 3 and $4.5 \mathrm{ml}$, respectively).

The analysis of $\mathrm{Ag}, \mathrm{As}, \mathrm{Cd}, \mathrm{Co}, \mathrm{Cr}, \mathrm{Cu}, \mathrm{Fe}, \mathrm{Mn}, \mathrm{Ni}, \mathrm{Pb}, \mathrm{Se}, \mathrm{V}$ and $\mathrm{Zn}$ required an extra step in the preparation protocol. These elements were analysed by Inductively Coupled Plasma Atomic Emission Spectrometry (Varian Vista-Pro ICP-OES) and Mass Spectrometry (ICP-MS II Series Thermo Fisher Scientific). Reference tissues - dogfish liver DOLT-4 (NRCC), lobster hepatopancreas TORT-2 (NRCC) - were treated and analysed in the same way as the samples. Results were in line with the certified values, and the standard deviations were low, proving good repeatability of the method. The results for standard reference materials displayed recovery of the elements ranging from $73 \%$ to $116 \%$. For each set of analyses, blanks were included in each analytical batch. The detection limits $\left(\mu \mathrm{g} \cdot \mathrm{g}^{-1} \mathrm{dw}\right)$ were 0.005 (Hg), 0.015 (Cd), 0.017 (Ag), 0.02 (Cr, Co, Pb), 0.03 (Ni), 0.08 (Mn), 0.1 (Cu, Se), 0.2 (As), $0.3(\mathrm{~V})$ and $3.3(\mathrm{Fe}$ and $\mathrm{Zn}$ ). All trace element concentrations are given on a dry weight basis $\left(\mu \mathrm{g} \cdot \mathrm{g}^{-1} \mathrm{dw}\right)$. 


\subsection{POP analyses}

\subsubsection{Choice of PCB congeners and pesticides}

The concentrations of 15 individual congeners (IUPAC Nos. 18, 20, 28, 31, 44, 52, 101, 105, 118, 138, 149, 153, 170, 180, 194; Ballschmiter and Zell 1980) were determined in each sample. This list contains the seven target congeners (PCBs 28, 52, 101, 118, 138, 153, 180) proposed by the International Council for the Exploration of the Sea (ICES) as indicators of PCB contamination (Valoppi et al. 2000).

The samples and blank were analyzed for the following pesticides: Aldrin, Diazinon, Dieldrin, Endosulfan I, Endosulfan II, Endrin, Heptachlor, Heptachlor-epoxide A, Heptachlorepoxide B, Lindane and, pp'-DDD, pp'-DDE, pp'-DDT.

\subsubsection{Sample extraction and quantification}

Compounds were extracted and quantified following the procedures described by Dierking et al. (2009). About $1 \mathrm{~g}$ of lyophilized sample was extracted and concentrated to 2 ml. About $100 \mu \mathrm{L}$ of this extract was reserved to determine the content of lipid (Lp, \%) of each sample (see next paragraph). The remaining fraction was purified with concentrated sulphuric acid, followed by additional purification by liquid chromatography on a silicaalumina column (Murphy 1972; Wells et al. 1985). Four fractions were eluted: fraction Ia (Aldrin, pp'-DDT, Heptachlor (50\%)), fraction Ib (Heptachlor (50\%), pp'-DDT), fraction II (Endosulfan I, Endosulfan II, Lindane, pp'-DDD) and fraction III (Dieldrin, Endrin, Heptachlor-epox A and B).

PCBs and pesticides were analysed by gas chromatography (GC) coupled to mass spectrometry (MS). Calibration was done using fifteen individual standard solutions for PCBs and a standard mixture containing all pesticides was used for pesticides. All organic pollutant concentrations are given on a dry weight basis $\left(\mathrm{ng} . \mathrm{g}^{-1} \mathrm{dw}\right.$ ). Detection limits were $0.01 \mathrm{ng} \cdot \mathrm{g}^{-1}$ for PBC congeners, $0.1 \mathrm{ng} \cdot \mathrm{g}^{-1}$ for DDT and its metabolites, $0.01 \mathrm{ng} \mathrm{g}^{-1}$ for Heptachlor-epoxide A and B, 0.1 ng. $\mathrm{g}^{-1}$ for Lindane, Diazinon, Heptachlor, Aldrin, Endosulfan II, Endrin and 0.2 ng.g ${ }^{-1}$ for Endosulfan I and Dieldrin. 


\section{$2.4 \delta^{15} N$ and lipid quantification}

The nitrogen stable-isotope ratio $\left(\delta^{15} \mathrm{~N}\right)$ was used to give an approximate trophic position. Analyses were carried out on dorsal white muscle, as this tissue gives the most reliable values (Pinnegar and Polunin 1999). Then $1 \pm 0.1 \mathrm{mg}$ of powdered freeze-dried samples was weighed out and sealed in tin capsules for analyses. ${ }^{15} \mathrm{~N} /{ }^{14} \mathrm{~N}$ ratios were determined by continuous-flow isotope-ratio mass spectrometry with a Thermo Scientific Delta V Advantage mass spectrometer coupled to a Thermo Scientific Flash EA1112 elemental analyser (Chouvelon et al. 2011). Results are expressed as isotope ratios $\delta^{15} \mathrm{~N}$ (\%) relative to international standard (atmospheric $\mathrm{N}_{2}$ for nitrogen), according to the formula:

$$
\delta^{15} \mathrm{~N}=\left[\left(\mathrm{R}_{\text {sample }} / \mathrm{R}_{\text {standard }}\right)-1\right] * 10^{3}
$$

where $\mathrm{R}={ }^{15} \mathrm{~N} /{ }^{14} \mathrm{~N}$ (Peterson and Fry 1987). Replicate measurements of internal laboratory standards (acetanilide) indicated a precision of approximately $0.2 \%$ for $\delta^{15} \mathrm{~N}$ values.

To evaluate the lipid content (Lp, \%) in each fish, $100 \mu \mathrm{L}$ of the evaporated extraction residue was introduced in an initially tarred (tablet) container; then the whole was deposited into a desiccator. After drying to constant mass, the lipid content is determined by gravimetry.

\subsection{Statistical analysis}

Several indices were used to characterize the POP contamination. Our PCB profiles revealed that PCBs detected in the environment mainly came from capacitors (pyralene: DP3, DP4 or Arochlor1230, 1242). Consequently it was decided to express the global footprint of PCB contamination (PCBTot) using the estimation proposed by Annema et al. (1995): PCBTot $=\Sigma(28+52+101+138+153+180) * 5$. IICES (sum of concentrations of the 7 ICES congeners), and the proportional contribution of each PCB class (tri- to octachlorinated) was also calculated using all of the PCBs analysed. The total DDT concentration, $\Sigma D D T$, was calculated as the sum of pp'-DDD, pp'-DDE and pp'-DDT. An indication of the timing of PCB inputs was estimated through the ratio of the two congeners CB153/CB138 (Monod et al. 1995; Wafo et al. 2005: a high ratio (> 1) indicates continuous inputs or persistence of PCBs in the environment, whereas a low ratio $(<1)$ reflects a decrease or 
sporadicity of PCB inputs or non-persistence. Finally, the ratio of the total concentration of pesticides to total concentration of PCBs analysed ( $\Sigma P e s t / \Sigma P C B)$ was used as an approximate indication of the relative importance of agricultural versus industrial sources of organic pollutants in the environment (de Mora et al. 2004); a ratio higher than 1 indicates prevalence of agricultural sources, whereas a ratio less than 1 indicates prevalence of industrial sources.

Data were log transformed to satisfy conditions of normality (Shapiro-Wilk test) and homogeneity of variance (Bartlett test). However for some compounds (Aldrin, Diazinon, Dieldrin, Endrin, pp'-DDD and pp'-DDT), transformation was not sufficient. When conditions were satisfied, parametric tests were used. In other cases non-parametric analogues were applied.

Principal component analysis (PCA) was used to obtain an overview of the contribution of each contaminant according to sites. Trace elements and POP concentrations were analysed in separate PCAs and as no clear patterns were revealed from POP analysis, only trace element results were presented. Spatial variability of contaminant concentrations in each species was also tested using 2-way ANOVA and Tukey's post hoc multiple comparisons. For all contaminants, Pearson or Spearman correlations were used to explore the relationship between both contaminant concentration and fish size (TL) and contaminant concentration and trophic level $\left(\delta^{15} \mathrm{~N}\right)$. For organic pollutants the relationship between contaminant concentration and the percentage of lipids in muscle (Lp) was also examined. When a correlation existed, ANCOVA, instead of ANOVA was applied, using TL, $\delta^{15} \mathrm{~N}$ or Lp as a covariate. $R$ project ( $R$ version 2.13.2) was the statistical program used for all analyses. The levels of significance for statistical analyses was always set at $\alpha=0.05$.

\section{Results}

\subsection{Accumulation levels in anguilliform fish}

All trace elements measured were detected in anguilliform fish, except $\mathrm{Ag}$ and $\mathrm{V}$ which were below the detection limit. Mean concentrations and ranges of detected values of contaminants (trace elements and POPs) in anguilliform fish muscle are presented in Table 2. Several elements showed a high inter-individual variability (i.e. $\mathrm{Cd}, \mathrm{Cr}, \mathrm{Ni}, \mathrm{Pb}$; coefficient of variation $\mathrm{CV}>100 \%$ ). However it was most often the same individuals that accumulated high 
concentrations of several trace elements linked to their origin (e.g. a G. chilospilus specimen from the coastal site of Grand Nouméa; $35.7 \mu \mathrm{g} \cdot \mathrm{g}^{-1} \mathrm{dw}$ of $\mathrm{Cr}$ and $17.4 \mu \mathrm{g} \cdot \mathrm{g}^{-1} \mathrm{dw}$ of $\mathrm{Ni}$ ).

Overall, few differences in mean contaminant concentrations were found between species. However, significantly higher concentrations of As, $\mathrm{Hg}$ and Se were measured in Conger sp., whereas G. chilospilus exhibited higher concentrations of $\mathrm{Cd}$ and $\mathrm{Zn}$ ( $\mathrm{p}_{\mathrm{ANOVA}}<$ 0.001). PCBs had been similarly accumulated by both species, albeit weak interspecific differences were detected for pesticides: Conger sp. presented significantly higher concentrations of Heptachlor, Heptachlor-epoxy B ( $\mathrm{p}_{\text {ANOVA }}<0.01$ ), while slightly higher concentrations of Endosulfan I and Aldrin were measured in G. chilospilus ( $\mathrm{p}_{\text {ANOVA }}<0.05$ ).

\subsection{Spatial patterns in contaminants}

\subsubsection{Trace elements}

A significant spatial variability of several trace elements, in particular those linked with mining activity ( $\mathrm{Co}, \mathrm{Cr}, \mathrm{Fe}, \mathrm{Mn}$ and $\mathrm{Ni}$ ), was detected along the coast-barrier reef gradient (Fig. 2 and Table 3). The PCAs in G. chilospilus indicated that the coastal sites were characterized by $\mathrm{Co}, \mathrm{Mn}$ and $\mathrm{Ni}$ elements, in contrast to the barrier reef sites which were characterised by As and Cd concentrations (the plot of the first two PCA dimensions explained respectively $51.1 \%$ and $59.0 \%$ of data variability in G. chilospilus and Conger sp., Fig. 2). In Conger sp., the difference between sites was even stronger, with most trace elements (As, Co, Cr, Fe, Ni, Se, and $\mathrm{Zn}$ ) characterising coastal sites. These general trends were confirmed by the significantly higher concentrations of mine elements at coastal sites for both species ( $\mathrm{p}_{\text {ANOVA }}$ or $\mathrm{p}_{\text {ANCOVA }}<0.05$, Table 3 ).

The same spatial pattern (coast vs. barrier reef) was revealed in the two studied areas (GN and GS, Table 3 and S1). The coastal site of Grand Nouméa showed significantly higher concentrations of $\mathrm{Ni}$ in G. chilospilus ( $\left.\mathrm{p}_{\mathrm{ANOVA}}=0.02\right)$ and $\mathrm{Cr}$ and $\mathrm{Fe}$ in Conger $\mathrm{sp}$. ( $\mathrm{p}_{\mathrm{ANOVA}}<$ 0.05 , Table 3 and S1), with the same trends followed by several other trace elements $(\mathrm{Cr}, \mathrm{Fe}$ in G. chilospilus, As, $\mathrm{Co}, \mathrm{Cu}, \mathrm{Ni}, \mathrm{Se}$, and $\mathrm{Zn}$ in Conger sp., results of PCA not shown). However in Grand Lagon Sud the spatial gradient was less pronounced. The coastal site was characterized by higher Co and Mn concentrations in both species (results of PCA not shown), but spatial analyses only suggested significantly lower concentrations of $\mathrm{As}$ and $\mathrm{Cd}$ in G. chilospilus ( $\mathrm{p}_{\mathrm{ANCOVA}}=0.001$, Tables 3 and $\mathrm{S} 1$ ). 
The coastal site of Grand Nouméa was characterized by significantly higher levels of several trace elements compared to Grand Lagon Sud (e.g. As, $\mathrm{Cd}$ and $\mathrm{Ni}$ in G. chilospilus, and $\mathrm{Cr}, \mathrm{Fe}$ in Conger sp.; $\mathrm{p}_{\mathrm{ANCOVA}}<0.05$, Tables 3 and $\mathrm{S} 1$ ).

\subsubsection{Organic pollutants}

The PCAs did not reveal any clear spatial pattern for POPs in either species (results not shown). Analyses suggested a low spatial variability along the coast-barrier reef gradient (Table 4).

The PCB contamination in G. chilospilus did not vary significantly between sites (see PCBTot index; $\left.\mathrm{p}_{\mathrm{ANOVA}}>0.05\right)$, in spite of a slight increase from the coast to the barrier reef. However in Conger sp. the intermediate sites were characterized by high concentrations ( $\mathrm{p}_{\text {ANCOVA }}<0.05$, Table 4). The $C B 153 / C B 138$ ratio, which was generally below 1 , showed few spatial variations and only G. chilospilus from coastal sites showed a significantly higher ratio $\left(\mathrm{p}_{\text {ANCOVA }}<0.05\right.$, Tables 4 and $\mathrm{S} 2$ ). The PCB chlorination classes differed slightly along the coast-barrier reef gradient and between studied areas, with a low variability detected in each case $\left(<10 \%, \mathrm{p}_{\mathrm{ANCOVA}}\right.$ or $\mathrm{p}_{\mathrm{ANOVA}}<0.05$, Table 4$)$. However the results highlighted a remarkable increase in the proportion of the most toxic chlorinated classes in coastal sites (i.e. 8Cl in GN for G. chilospilus and 7Cl in GS for Conger sp., $\mathrm{p}_{\mathrm{ANOVA}}<0.05$ ).

The results for pesticides indicated few spatial variations (Tables 4 and S2). The coastal sites highlighted significantly higher concentrations of some pesticides in G. chilospilus (Aldrin and Heptachlor, $\mathrm{p}_{\mathrm{ANCOVA}}$ or $\left.\mathrm{p}_{\mathrm{KW}}<0.05\right)$, whereas the intermediate reef sites revealed significantly higher rates of several other pesticides in Conger sp. (e.g. Diazinon, Heptachlor epoxide A and pp'-DDT; $\mathrm{p}_{\mathrm{ANCOVA}}$ or $\left.\mathrm{p}_{\mathrm{KW}}<0.05\right)$.

Finally, spatial analyses of POP contamination according to sources of pollution (agriculture $v s$. industrial) reinforce previous results (see $\Sigma P e s t / \Sigma P C B s$; Table 4). Along the gradient, G. chilospilus from the coastal sites were significantly different from other sites, with quite homogeneous sources of contamination (ratio $\geq 1$ ). In comparison industrial sources dominated in other sites (ratio $\cong 0.50, \mathrm{p}_{\mathrm{ANOVA}}<0.05$, Table 4 ). A strong influence of industrial pollution in intermediate sites (ratio $\cong 0.50, \mathrm{p}_{\mathrm{ANCOVA}}<0.05$ ) was also highlighted in Conger sp. 


\subsection{Influence of size, trophic position and lipid content on contamination level}

Several trace elements $(\mathrm{Co}, \mathrm{Cr}, \mathrm{Ni}, \mathrm{Pb}, \mathrm{Se}$, and $\mathrm{Zn}$ in $G$. chilospilus, $\mathrm{Cd}$ and $\mathrm{Mn}$ in Conger sp.) were not correlated with either the size or the trophic position of fish ( $\mathrm{p}_{\text {Pearson }}>$ 0.05), but some trace elements were significantly correlated with fish size (Table 5). Only As and $\mathrm{Hg}$ highlighted a positive relationship with the trophic position of fish $\left(\delta^{15} \mathrm{~N}\right)$ in Conger sp., whereas no correlation was found for G. chilospilus.

Organic pollutant concentrations were linked to size, trophic position or lipid content, depending on the contaminant. Most of them were mainly significantly correlated with the lipid contents in fish (Table 5). For example, PCBs were only correlated with lipids in both species. Pesticides were also correlated with Lp, and to a lesser extent with $\delta^{15} \mathrm{~N}$ and TL (Table 5).

\section{Discussion}

This study confirms, reinforces and extends the high trace element contamination status of anguilliform fish in New Caledonia (Bonnet et al. 2014). It also constitutes the first substantial baseline on organic pollutant contamination of fish in New Caledonia. Importantly, our results show that large scale contamination reaches remote parts of the lagoon, more than 30km offshore (SW lagoon), and thus well beyond the urbanized Nouméa region.

\subsection{Contaminant levels and spatial variability}

\subsubsection{Trace element patterns}

Anguilliform fish concentrate both significant levels of trace elements associated with mining exploitation ( $\mathrm{Cr}, \mathrm{Fe}, \mathrm{Mn}$, and $\mathrm{Ni}$ for both species), and also some elements linked to urban activities (e.g. Cd, $\mathrm{Cu}$ and $\mathrm{Zn}$, especially in G. chilospilus) (Table 2). This elevated typical mining signature detected in sedentary benthic species contrasts with other studies which highlight low contaminant levels in some more mobile fish in both the lagoons of New Caledonia and other tropical regions (Eisler 2010; Bonnet et al. 2014; Table 6).

Although coastal sites in New Caledonia are highly contaminated by trace elements, directly or indirectly linked to mining activity $(\mathrm{Co}, \mathrm{Cr}, \mathrm{Fe}, \mathrm{Mn}$ and $\mathrm{Ni})$, the contamination has 
spread throughout the entire lagoon as far as the remote barrier reef of the extremely vast South-Western lagoon. This is probably due to dispersal by local currents (Fichez et al. 2008). However, it should be noted that concentrations decrease significantly from the coast to the barrier reef.

Unsurprisingly, fish from the coastal site in Grand Nouméa present important concentrations in trace elements, especially $\mathrm{Cr}, \mathrm{Fe}$ and $\mathrm{Ni}$ (Table 3). This urbanized and industrialized region is subjected to clear impact from the metallurgic industry (Hédouin et al. 2009, 2011; Metian et al. 2008, 2013). In contrast, the Grand Lagon Sud is less impacted by trace element inputs. Even if coastal sites in this area seem to be less threatened, trends still reveal important concentrations of $\mathrm{Co}, \mathrm{Mn}$ and $\mathrm{Ni}$ (Table 3). This strong contamination level likely results from severe soil erosion, due to deforestation and mining exploitation in this region over several decades. Given the numerous mines in New Caledonia and the intensive development of mining activities, assessing to what extent other areas of the New Caledonian lagoon have been affected is timely.

We expected a strong impact of urban pollution at least in Grand Nouméa sites, given the intense activity in the coastal industrial area of Ducos. However, while spatial patterns are obvious for trace elements associated with mining activities, those associated with urban pollution (As, $\mathrm{Cd}, \mathrm{Cu}, \mathrm{Pb}$ and $\mathrm{Zn}$ ) are less clear. Whereas $\mathrm{Se}$ and $\mathrm{Zn}$ are mostly concentrated in coastal sites for Conger sp., $\mathrm{Cu}$ and $\mathrm{Pb}$ are homogeneously distributed along the coastbarrier reef gradient. Furthermore, the cases of As and $\mathrm{Cd}$ are more complex with sometimes higher concentrations (e.g. As in Conger sp.) and sometimes lower concentrations in coastal sites (e.g. As and $\mathrm{Cd}$ in G. chilospilus). Finally elements issued from urban pollution concern the entire lagoon, maybe due to their wide dispersal by local currents (Fichez et al. 2008). Another possible explanation is that in the past some islets were used as rubbish tips for decades (e.g. Amédée islet in Nouméa region, Bonnet et al. 2014). Further information on these issues is thus needed.

\subsubsection{Organic pollutant patterns}

Contamination by POPs detected in anguilliform fish was rather low. However, considering the high toxicity of some POPs, even at very low doses, this contamination should be considered as important. Levels of PCB concentrations recorded in New Caledonia are generally lower than in fish from other tropical or temperate regions (e.g. $\Sigma I C E S$ index in 
New Caledonia: $14.0 \pm 12.2$ ng. $\mathrm{g}^{-1} \mathrm{dw}\left(G\right.$. chilospilus) and $16.5 \pm 14.3 \mathrm{ng} \cdot \mathrm{g}^{-1} \mathrm{dw}$ (Conger sp.); in Wallis Central Pacific: $31.3 \pm 9.6 \mathrm{ng} . \mathrm{g}^{-1} \mathrm{dw}($ Cephalopholis argus) and $49.7 \pm 45.3$ ng. ${ }^{-1} \mathrm{dw}$ (Epinephelus merra) (Letourneur et al., unpublished data); in the Mediterranean Sea: $100.6 \mathrm{ng} \cdot \mathrm{g}^{-1} \mathrm{dw}$ (Solea solea) (Dierking et al. 2009)). Exposure profiles of PCBs showed a contribution of chlorination classes in both species, with the prevalence of moderately chlorinated classes $(5 \mathrm{Cl}$ and $6 \mathrm{Cl})$ and the scarcity of highly chlorinated classes $(7 \mathrm{Cl}$ and $8 \mathrm{Cl})$. These results emphasize a recent or even current use of PCBs in New Caledonia, otherwise only the more persistent classes (highly chlorinated) should be detected. Further studies are needed to confirm this hypothesis.

In New Caledonian fish, pesticide concentrations are equivalent or lower than in other regions (e.g. Lindane in New Caledonia: $1.3 \pm 0.6 \mathrm{ng} \cdot \mathrm{g}^{-1} \mathrm{dw}(G$. chilospilus) and $1.7 \pm 1.6$ (Conger sp.); in Wallis Central Pacific: $3.5 \pm 1.03$ ng. $\mathrm{g}^{-1} \mathrm{dw}($ C. argus $)$ and $3.6 \pm 2.07 \mathrm{ng} . \mathrm{g}^{-1}$ $\mathrm{dw}$ (E. merra) (Letourneur et al., unpublished data); in French Polynesia: $73.3 \pm 34.5 \mathrm{ng} . \mathrm{g}^{-1}$

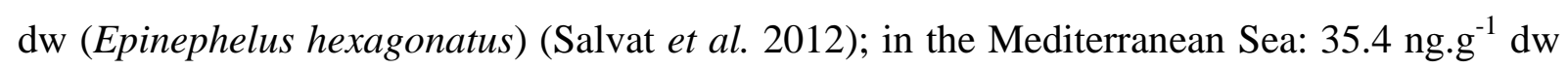
(Solea solea) (Dierking et al. 2009)). Despite the quantities and diversity of pesticides imported into New Caledonia, these low levels detected reflect their relatively moderate use, which probably comes from local and non-professional activities rather than from the agricultural industry. In addition, Nouméa is located far from the most important agricultural areas. This type of non-professional use could also explain a non-negligible detection of pesticides such as DDT and its metabolites (i.e. $\Sigma D D T: 1.55 \pm 1.50 \mathrm{ng} . \mathrm{g}^{-1} \mathrm{dw}$ in G. chilospilus and $1.57 \pm 1.48$ in Conger sp.), which are supposed to be prohibited by international regulations and not homologated in New Caledonia (DAVAR, 2001).

Overall, POP concentrations are homogeneous throughout the lagoon, without any clear spatial pattern along the coast-barrier reef gradient, or between studied areas. Nevertheless, some high pesticide concentrations in G. chilospilus were observed in several coastal sites and in intermediate reefs, with high PCB and some high pesticide levels in Conger sp. (Tables 4 and S2). Storage organs (i.e. liver, kidney or digestive gland) usually accumulate higher concentrations than muscle (e.g. Bustamante et al. 2003; Chouvelon et al. 2009; Metian et al. 2013; Eisler 2010). Further research is required to test this notion in Anguilliforms and thus to better assess spatial contamination gradients, especially for POPs.

The results underlined the complexity in identifying the agricultural and/or industrial origin of organic contamination for each site (see $\Sigma P e s t / \Sigma P C B s$ ratio, Table 4). Trends seem to emphasize a slight prevalence of agricultural contamination sources at coastal sites, in 
comparison with other sites dominated by industrial pollution. Furthermore, the Nouméa area generally seems to be more exposed to industrial contamination, whereas Grand Lagon Sud has revealed strong local agricultural pollution (except at intermediate reefs, Table S2). In Grand Nouméa, anguilliform fish have not been exposed to PCB inputs in recent times in view of their low $C B 153 / C B 138$ ratio (i.e. ratio $<0.8, \approx 0.75$ in $G$. chilospilus and $\approx 0.78$ in Conger sp., Table S2). On the other hand, the PCB inputs in Grand Lagon Sud seem to be more recent mainly in coastal sites, as detected in both species (ratio > 1, 1.64 in $G$. chilospilus and 1.04 in Conger sp., Table S2). Industrial activities in this area, including the recent construction of a mining factory, could explain in part the continuing inputs of PCBs in this area.

\subsection{Influence of biological parameters on contamination level}

As mentioned in several studies, concentrations of contaminants can also vary according to ecological and biological factors such as fish size (or age), trophic position and feeding habits or lipid content (Monteiro et al. 1991; Geyer et al. 2000; Penedo de Pinho et al. 2002). These complex relationships can induce interspecific differences in bioaccumulation processes and so emphasize the relevance in detecting the contamination rate at a specific level.

Our results indicated the influence of the three factors tested (body size, trophic position and lipid content) on several contaminants in both species. The link between body size and bioaccumulation is complex, depending on both the contaminants and the fish species considered. In some cases, trace elements accumulated with increasing fish size (e.g. As, $\mathrm{Cd}$ and $\mathrm{Hg}$ in G. chilospilus, Table 5), which is consistent with continuous bioaccumulation in muscle during life span (Braune 1987; Burger and Gochfeld 2007; Bloom 1992). In some other cases, trace element concentration is negatively correlated with size (e.g. $\mathrm{Cu}$ and $\mathrm{Fe}$ in both species, or $\mathrm{Co}, \mathrm{Cr}, \mathrm{Ni}, \mathrm{Pb}, \mathrm{Se}$ and $\mathrm{Zn}$ in Conger sp.). This trend could be explained by a decrease in assimilation or by more efficient elimination processes with increasing fish size (Braune 1987, Swaileh and Adelung 1995, Warnau et al. 1995). Such a relationship can also suggest that an ontogenetic diet shift might occur, implying a variation in the exposure to contaminants through the food pathway, as found in other species (Chouvelon et al. 2011, Chouvelon et al. 2014). However, with the exception of $\mathrm{Hg}$, and to a lesser extent Se, biomagnification of trace elements in trophic webs is still unclear and difficult to identify (Wang 2002). For anguilliform fish from New Caledonia, the trophic position influenced As 
and $\mathrm{Hg}$ concentrations only in Conger sp. The POP results are in accordance with their hydrophobic nature, which allows their sequestration in fat tissues during the process of organochlorine accumulation (Robertson and Hansen 2001). Most of them were indeed positively linked to the lipid content of fish, in particular in Conger sp., where lipid variation ranged between 0.2 and $5.5 \%$ (Table 1 ).

Measures of $\delta^{15} \mathrm{~N}$ in fish confirm the high trophic level of anguilliform fish (Brischoux et al. 2011). When this is associated with other life history traits (size, age, longevity, philopatry, etc.), the detection of high trace element levels appears consistent. These benthic predators are also probably good candidates for monitoring organic pollution because of the strong relationship of POPs with lipid content (even if the flesh of these fish is not very fatty). The specific biological characteristics of each species may well explain interspecific differences in bioaccumulation of contaminants.

Moreover, contamination of anguilliform fish (high trophic level predators) suggests that trophic networks in general are contaminated (Monniot et al. 1994; Hédouin et al. 2006, 2007; Metian et al. 2008b). As a consequence, it is important to carry out contaminant analysis in prey, top predators (e.g. sea snakes, Bonnet 2012) and in the global trophic web. This will provide a more complete assessment of contamination of the environment and lead to better understanding of the mechanisms and processes involved (e.g. bioaccumulation, biomagnification, Bryan 1984; Rainbow 1993). A good understanding of both the organisms (i.e. biology, ecology and metabolic capacities) and the trophic network structures, plus environmental conditions, is necessary to understand the dynamics of bioaccumulation and biomagnification throughout the trophic webs (Harmelin-Vivien et al. 2009).

\section{Conclusion}

This study strongly confirms a clear accumulation of trace metal contaminants in the muscles of anguilliform fish and the obvious coastal contamination by trace elements linked to mining activities. It is also shown that contamination by POPs occurs in the whole lagoon. These results raise an alert about complex contaminations throughout the lagoon on a large spatial scale. Various contaminants may show different behaviour in abiotic and biotic environments. Due to their lipophilic nature, POPs have different targets compared to trace elements. This characteristic can explain in part their divergences in mobility in comparison to trace elements. Thus, the more widespread repartition of POPs within the lagoon is 
probably due to their great capacity of dispersion, through atmospheric transport and currentdriven dilution during tropical rain events. This highlights the importance of considering multiple sources of contamination. Moreover, the possibility of a cocktail effect of these various contaminants is not known and could increase the threat. Therefore, in the future, long term monitoring studies and experiments on toxicity are necessary.

\section{Acknowledgments}

This work was funded by the Fondation Total and the Ecole Doctorale du Pacifique (ED 469) through a PhD grant to MB. We thank the DENV (Province Sud) and E. Potut (Scaphca) for logistic support during the sampling. We are grateful to the many volunteers who participated in the fieldwork. We also thank C. Pigot and C. Goiran (Université de la Nouvelle-Calédonie) for their contribution in field and laboratory work. The study was carried out under permit 930-2011/ARR/DENV (28 March 2001) issued by the DENV, Province Sud, New Caledonia.

\section{References}

Ambastian P, Fernex F, Bernat M, Parron C, Lecolle J (1997) High metal inputs to closed seas: the New Caledonia lagoon. Journal of Geochemistry Exploration 59, 59-74.

Annema JA, Beurskens JEM, Bodar CWM (1995) Evaluation of PCB fluxes in the environment. The Netherlands: National Institute of Public Health and Environmental Protection Bilthoven, Report N6010144011. 87pp.

Adams DH, McMichael RH (1999) Mercury levels in four species of sharks from the Atlantic coast of Florida. Fishery Bulletin, 97 (2):372-379.

Ballschmiter K, Zell M (1980) Analysis of polychlorinated biphenyls (PCB) by glass capillary gas chromatography. Fresenius' Zeitschrift für analytische Chemie, 302 (1):20-31.

Bloom NS (1992) On the chemical form of mercury in edible fish and marine invertebrate tissue. Canadian Journal of Fisheries and Aquatic Sciences, 49(5), 1010-1017.

Bonnet X (2012) Long-term field study of sea kraits in New Caledonia: fundamental issues and conservation. Integrative and Comparative Biology, 52(2), 281-295.

Bonnet X, Briand MJ, Brischoux F, Letourneur Y, Fauvel T, Bustamante P (2014) Anguilliform fish reveal large scale contamination by trace elements in the coral reefs of New Caledonia. Science of the Total Environment DOI: $10.1016 /$ j.scitotenv.2013.10.027 
Braune B (1987) Mercury accumulation in relation to size and age of Atlantic herring (Clupea harengus harengus) from the southwestern Bay of Fundy, Canada. Archives of Environmental Contamination and Toxicology, 16 (3):311-320.

Brischoux F, Bonnet X, Shine R (2007a) Foraging ecology of sea kraits (Laticauda spp.) in the Neo-Caledonian lagoon. Marine Ecology Progress Series, 350:145-151.

Brischoux F, Bonnet X, De Crignis M (2007b) A method to reconstruct anguilliform fishes from partially digested items. Marine Biology, 151 (5):1893-1897.

Brischoux F, Bonnet X (2008) Estimating the impact of sea kraits on the anguilliform fish community (Muraenidae, Congridae, Ophichthidae) of New Caledonia. Aquatic Living Resources, 21:395-399.

Brischoux F, Bonnet X (2009) Life history of sea kraits in New Caledonia. Mémoires du Muséum d'Histoire naturelle, 198:133-147.

Brischoux F, Bonnet X, Legagneux P (2009) Are sea snakes pertinent bio-indicators for coral reefs? A comparison between species and sites. Marine Biology, 156:1985-1992.

Brischoux F, Bonnet X, Cherel Y, Shine R (2011) Isotopic signatures, foraging habitats and trophic relationships between fish and seasnakes on the coral reefs of New Caledonia. Coral Reefs, 30 (1):155-165.

Bryan GW (1984) Pollution due to heavy metals and their compounds. Marine Ecology 5: 1290-33.1

Burger J, Gochfeld M, Jeitner C, Burke S, Stamm T, Snigaroff R, Snigaroff D, Patrick R, Weston J (2007) Mercury levels and potential risk from subsistence foods from the Aleutians. Science of The Total Environment, 384 (1-3):93-105.

Bustamante P, Grigioni S, Boucher-Rodoni R, Caurant F, Miramand P (2000) Bioaccumulation of 12 trace elements in the tissues of the Nautilus Nautilus macromphalus from New Caledonia. Marine Pollution Bulletin, 40 (8):688-696.

Bustamante P, Bocher P, Chérel Y, Miramand P, Caurant F (2003) Distribution of trace elements in the tissues of benthic and pelagic fish from the Kerguelen Islands. Science of The Total Environment, 313 (1-3):25-39.

Bustamante P, Lahaye V, Durnez C, Churlaud C, Caurant F (2006) Total and organic Hg concentrations in cephalopods from the North Eastern Atlantic waters: Influence of geographical origin and feeding ecology. Science of The Total Environment, 368 (23):585-596. 
Chouvelon T, Warnau M, Churlaud C, Bustamante P (2009) Hg concentrations and related risk assessment in coral reef crustaceans, molluscs and fish from New Caledonia. Environmental Pollution, 157 (1):331-340.

Chouvelon T, Spitz J, Cherel Y, Caurant F, Sirmel R, Mèndez-Fernandez P, Bustamante (2011) Species and ontogenic-related differences in $\delta^{13} \mathrm{C}$ and $\delta^{15} \mathrm{~N}$ values and $\mathrm{Hg}$ and Cd concentrations of cephalopods. Marine Ecology Progress Series, 433:107-120.

Chouvelon T, Caurant F, Cherel Y, Simon-Bouhet B, Spitz J, Bustamante P (2014) Sizerelated patterns in stable isotopes and mercury concentrations in fish help refining marine ecosystem indicators and evidence distinct management units for hake in the north-eastern Atlantic. ICES Journal of Marine Sciences.

DOI: 10.1093/icesjms/fst199.

Dalvi AD, Bacon WG, Osborne RC (2004) The past and the future of nickel laterites. In: PDAC International Convention, Trade Show \& Investors Exchange. Toronto: The prospectors and Developers Association of Canada, 2004. p. 7-10.

DAVAR 2001. http://davar.gouv.nc/

de Mora S, Villeneuve J-P, Reza Sheikholeslami M, Cattini C, Tolosa I (2004) Organochlorinated compounds in Caspian Sea sediments. Marine Pollution Bulletin, $48(1-2): 30-43$.

Dierking J, Wafo E, Schembri T, Lagadec V, Nicolas C, Letourneur Y, Harmelin-Vivien ML (2009) Spatial patterns in PCBs, pesticides, mercury and cadmium in the common sole in the NW Mediterranean Sea, and a novel use of contaminants as biomarkers. Marine Pollution Bulletin, 58:1605-1614.

Domi N, Bouquegneau JM, Das K (2005) Feeding ecology of five commercial shark species of the Celtic Sea through stable isotope and trace metal analysis. Marine Environmental Research, 60 (5):551-569.

Dummee V, Kruatrachue M, Trinachartvanit W, Tanhan P, Pokethitiyook P, Damrongphol P (2012) Bioaccumulation of heavy metals in water, sediments, aquatic plant and histopathological effects on the golden apple snail in Beung Boraphet reservoir, Thailand. Ecotoxicology and Environmental Safety, 86:204-212.

Eilser R (2010) Compendium of trace metals and marine biota 2: Vertebrates. Elsevier, 522 p. Fauvel T, Brischoux F, Briand MJ, Bonnet X (2012) Do researchers impact their study populations? Assessing the effect of field procedures in a long term population monitoring of sea kraits. Amphibia-Reptilia:1-8. 
Fernandez J-M, Ouillon S, Chevillon C, Douillet P, Fichez R, Gendre RL (2006) A combined modelling and geochemical study of the fate of terrigenous inputs from mixed natural and mining sources in a coral reef lagoon (New Caledonia). Marine Pollution Bulletin, 52 (3):320-331.

Fernandez J-M and Breau L (2011) Impact potentiel de l'effluent de Vale NC sur le milieu marin (2005---2011). Rapport AEL 110328-OE-03, 209p.

Fichez R, Breau L, Chevillon C, Chifflet S, Douillet P, Faure V, Fernandez J-M, Gérard P, Hédouin L, Lapetite A, Ouillon S, Pringault O, Torréton J-P (2008) Origine, transport et devenir des apports naturels et anthropiques dans le lagon sud-ouest de NouvelleCalédonie. Le Journal de la Société des Océanistes, 126-127:41-58.

Geyer H, Rimkus G, Scheunert I, Kaune A, Schramm K-W, Kettrup A, Zeeman M, Muir DG, Hansen L, Mackay D (2000) Bioaccumulation and Occurrence of EndocrineDisrupting Chemicals (EDCs), Persistent Organic Pollutants (POPs), and Other Organic Compounds in Fish and Other Organisms Including Humans. Bioaccumulation, New Aspects and Developments. Handbook of Environmental Chemistry 2-J. Springer Verlag, Berlin, pp. 1-166.

Harmelin-Vivien ML, Cossa D, Crochet S, Banaru D, Letourneur Y, Mellon-Duval C (2009) Difference of mercury bioaccumulation in red mullets from the north-western Mediterranean and Black seas. Marine Pollution Bulletin, 58:679-685.

Hédouin L, Metian M, Teyssié J-L, Fowler SW, Fichez R, Warnau M (2006) Allometric relationship in the bioconcentration of heavy metals by the edible tropical clam Gafrarium tumidum. Science of The Total Environment, 336:154-163.

Hédouin L, Pringault O, Metian M, Bustamante P, Warnau M (2007) Nickel bioaccumulation in bivalves from the New Caledonia lagoon: Seawater and food exposure. Chemosphere, 66 (8):1449-1457.

Hédouin L, Bustamante P, Fichez R, Warnau M (2008) The tropical brown alga Lobophora variegata as a bioindicator of mining contamination in the New Caledonia lagoon: A field transplantation study. Marine Environmental Research, 66 (4):438-444.

Hédouin L, Bustamante P, Churlaud C, Pringault O, Fichez R, Warnau M (2009) Trends in concentrations of selected metalloid and metals in two bivalves from the coral reefs in the SW lagoon of New Caledonia. Ecotoxicology and Environmental Safety, 72 (2):372-381.

Hédouin L, Batista MG, Metian M, Buschiazzo E, Warnau M (2010) Metal and metalloid bioconcentration capacity of two tropical bivalves for monitoring the impact of land- 
based mining activities in the New Caledonia lagoon. Marine Pollution Bulletin, 61 (7-12):554-567.

Hédouin L, Pringault O, Bustamante P, Fichez R, Warnau M (2011) Validation of two tropical marine bivalves as bioindicators of mining contamination in the New Caledonia lagoon: Field transplantation experiments. Water Research, 45 (2):483-496. Hellawell JM (1988) Toxic substances in rivers and streams. Environmental Pollution, 50 (12):61-85.

Ineich I, Bonnet X, Brischoux F, Kulbicki M, Séret B, Shine R (2007) Anguilliform fishes and sea kraits: neglected predators in coral-reef ecosystems. Marine Biology, 151 (2):793-802.

Johnson GW, Quensen III JF, Chiarenzelli JR, Hamilton MC (2005) Polychlorinated Biphenyls. In: Morrison, R., Murphy, B. (Eds.), Environmental Forensics. Academic Press, pp. 187-225.

Kojadinovic J, Potier M, Le Corre M, Cosson RP, Bustamante P (2007) Bioaccumulation of trace elements in pelagic fish from the Western Indian Ocean. Environmental Pollution, 146 (2):548-566.

Lodenius M (1991) Mercury concentrations in an aquatic ecosystem during twenty years following abatement the pollution source. Water Air and Soil Pollution, 56 (1):323332.

Metian M, Bustamante P, Hédouin L, Warnau M (2008a) Accumulation of nine metals and one metalloid in the tropical scallop Comptopallium radula from coral reefs in New Caledonia. Environmental Pollution, 152 (3):543-552.

Metian M, Giron E, Borne V, Hédouin L, Teyssié J-L, Warnau M (2008b) The brown alga Lobophora variegata, a bioindicator species for surveying metal contamination in tropical marine environments. Journal of Experimental Marine Biology and Ecology, $362(1): 49-54$.

Metian M, Hédouin L, Eltayeb M, Lacoue-Labarthe T, Teyssié J-L, Mugnier C, Bustamante P, Warnau M (2010) Metal and metalloid bioaccumulation in the Pacific blue shrimp Litopenaeus stylirostris (Stimpson) from New Caledonia: Laboratory and field studies. Marine Pollution Bulletin, 61 (7-12):576-584.

Metian M, Warnau M, Chouvelon T, Pedraza F, Rodriguez y Baena A, Bustamante P (2013) Trace element bioaccumulation in reef fish from New Caledonia: influence of trophic groups and risk assessment for consumers. Marine Environmental Research, 87-88: 26-36. 
Monniot F, Martoja R, Monniot C (1994) Cellular sites of iron and nickel accumulation in ascidians related to the naturally and anthropic enriched New Caledonian environment. Annales de l'Institut Océanographique 70: 205-216.

Monod JL, Arnaud PM, Arnoux A (1995) PCB congeners in the marine Biota of Saint Paul and Amsterdam Islands, Southern Indian Ocean. Marine Pollution Bulletin 30 (4):272274.

Monteiro LR, Isidro EJ, Lopes HD (1991) Mercury content in relation to sex, size, age and growth in two scorpionfish (Helicolenus dactylopterus and Pontinus kuhlii) from Azorean waters. Water Air and Soil Pollution, 56 (1):359-367.

Murphy PG (1972) Sulfuric acid for the cleanup of animal tissues for analysis of acid stable chlorinated hydrocarbons residues. Journal Association of Official Analytical Chemists 55: 45-53

Penedo de Pinho A, Guimaraes JRD, Martins AS, Costa PAS, Olavo G, Valentin J (2002) Total mercury in muscle tissues of five shark species grom Brazilian offshore waters: effects of feeding habit, sex, and length. Environmental Research, Section A 89:250258.

Perez T, Wafo E, Fourt M, Vacelet J (2003) Marine Sponges as biomonitor of Polychlorobiphenyl Contamination: concentration and fate of 24 Congeners. Environmental Science and Technology, 37 (10):2152-2158.

Pernice M, Boucher J, Boucher-Rodoni R, Joannot P, Bustamante P (2009) Comparative bioaccumulation of trace elements between Nautilus pompilius and Nautilus macromphalus (Cephalopoda: Nautiloidea) from Vanuatu and New Caledonia. Ecotoxicology and Environmental Safety, 72 (2):365-371.

Peterson BJ, Fry B (1987) Stable isotopes in ecosystem studies. Annual Review of Ecology and Systematics, 18:293-320.

Phillips DJH (1995) The chemistries and environmental fates of trace metals and organochlorines in aquatic ecosystems. Marine Pollution Bulletin, 31 (4-12):193-200.

Pinnegar JK, Polunin NVC (1999) Differential fractionation of $\delta^{13} \mathrm{C}$ and $\delta^{15} \mathrm{~N}$ among fish tissues: implications for the study of trophic interactions. Functional Ecology, 13 (2):225-231.

Rainbow PS, Phillips DJ (1993) Cosmopolitan biomonitors of trace metals. Marine Pollution Bulletin, 26(11), 593-601. 
Reed RN, Shine R, Shetty S, Montgomery WL (2002) Sea kraits (Squamata: Laticauda spp.) as a useful bioassay for assessing local diversity of eels (Muraenidae, Congridae) in the Western Pacific Ocean. Copeia, 2002 (4):1098-1101.

Richmond RH (1993) Coral reefs: present problems and future concerns resulting from anthropogenic disturbance. American Zoologist, 33:524-536.

Robertson LW, Hansen LG (2001) PCBs: Recent advances in environmental toxicology and health effects. The University Press of Kentucky.

Sinkkonen S, Paasivirta J (2000) Degradation half-life times of PCDDs, PCDFs and PCBs for environmental fate modeling. Chemosphere, 40 (9-11):943-949.

Salvat B, Roche H, Berny P, Ramade F (2012) Recherches sur la contamination par les pesticides d'organismes marins des réseaux trophiques récifaux de Polynésie Française. Paris, FRANCE: Société nationale de protection de la nature et d'acclimatation de France, 19.

Swaileh KM, Adelung D (1995) Effect of body size and season on the concentrations of Cu, $\mathrm{Cd}, \mathrm{Pb}$ and $\mathrm{Zn}$ in Diastylis rathkei (kröyer) (Crustacea: Cumacea) from Kiel Bay, Western Baltic. Marine Pollution Bulletin, 31 (1-3):103-107.

Valoppi L, Petreas M, Donohoe RM, Sullivan L, Callahan CA (eds), (2000) Use of PCB congener and homologue analysis in ecological risk assessment. USA: American Society for Testing and Materials. In: Price, F.T., Brix, K.V., Lane, N.K. (Eds.), Environmental Toxicology and Risk Assessment: Recent Achievements in Environmental Fate and Transport, vol. 9. ASTM International, West Conshohocken, PA, USA, Pp. 147-161.

Van Ael E, Covaci A, Blust R, Bervoets L (2012) Persistent organic pollutants in the Scheldt estuary: environmental distribution and bioaccumulation. Environment International, 48:17-27.

Wafo E, Sarrazin L, Diana C, Dhermain F, Schembri Th, Lagadec V, Pecchia M, Rebouillon P (2005) Accumulation and distribution of organochlorines (PCBs and DDTs) in various organs of Stenella coeruleoalba and a Tursiops truncatus from Mediterranean littoral environment. Science of the Total Environment 348, 115-127.

Wafo E, Risoul V, Schembri T, Lagadec V, Dhermain F, Mama C and Portugal H (2012) PCBs and DDTs in Stenella coeruleoalba dolphins from the French Mediterranean coastal environment (2007-2009): Current state of contamination. Marine Pollution Bulletin, 64 (11):2535-2541. 
Wang WX (2002) Interactions of trace metal and different marine food chains. Marine Ecology Progress Series, 243:295-309.

Warnau M, Ledent G, Temara A, Alva V, Jangoux M, Dubois P (1995) Allometry of heavy metal bioconcentration in the echinoid Paracentrotus lividus. Archives of Environmental Contamination and Toxicology, 29 (3):393-399.

Wells DE, Cowan A, Christie AEG (1985) Separation of organochlorine residue by absorption chromatography prior to capillary gas chromatography. Journal of Chromatography, 328, 372-377. 


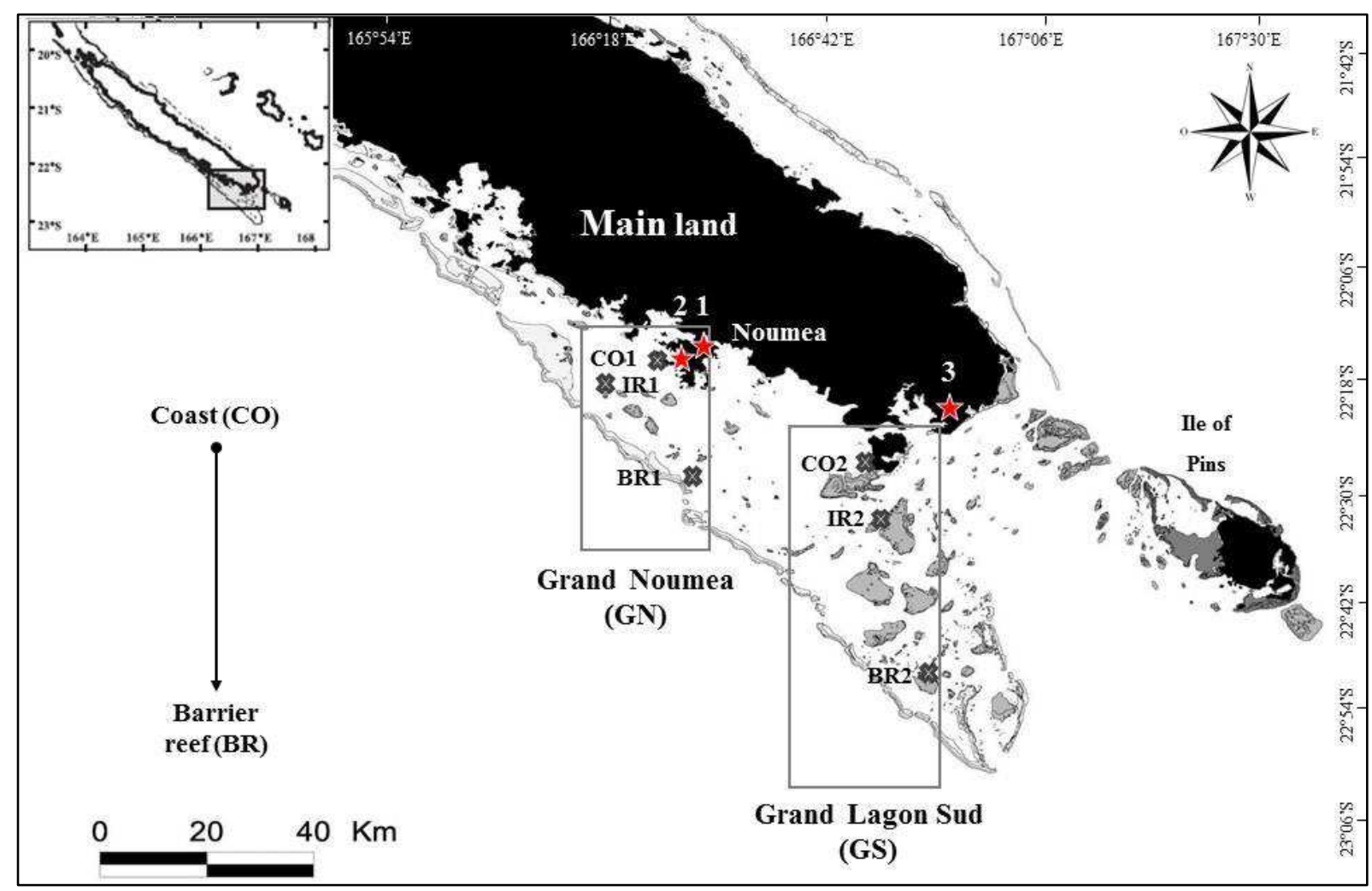

Figure 1. Location of the sampled sites distributed on two coast-barrier reef gradients in New Caledonia: Kuendu (CO1), Signal (IR1) and Amédée (BR1) in Grand Nouméa (GN) and Ouen (CO2), Grand Mato (IR2) and N'Da (BR2) in Grand Lagon Sud. CO = coastal sites; IR $=$ intermediate reef sites; $\mathrm{BR}=$ barrier reef sites. Stars indicate areas of human activities, which are the undustrial area of Ducos (1), the Nikel factory «SLN » (2) and the Nikel factory «Goro-Nikel » (3). The emerged land is indicated in black, grey areas represent coral reefs; the dark grey line represents the slope of the barrier reef. 

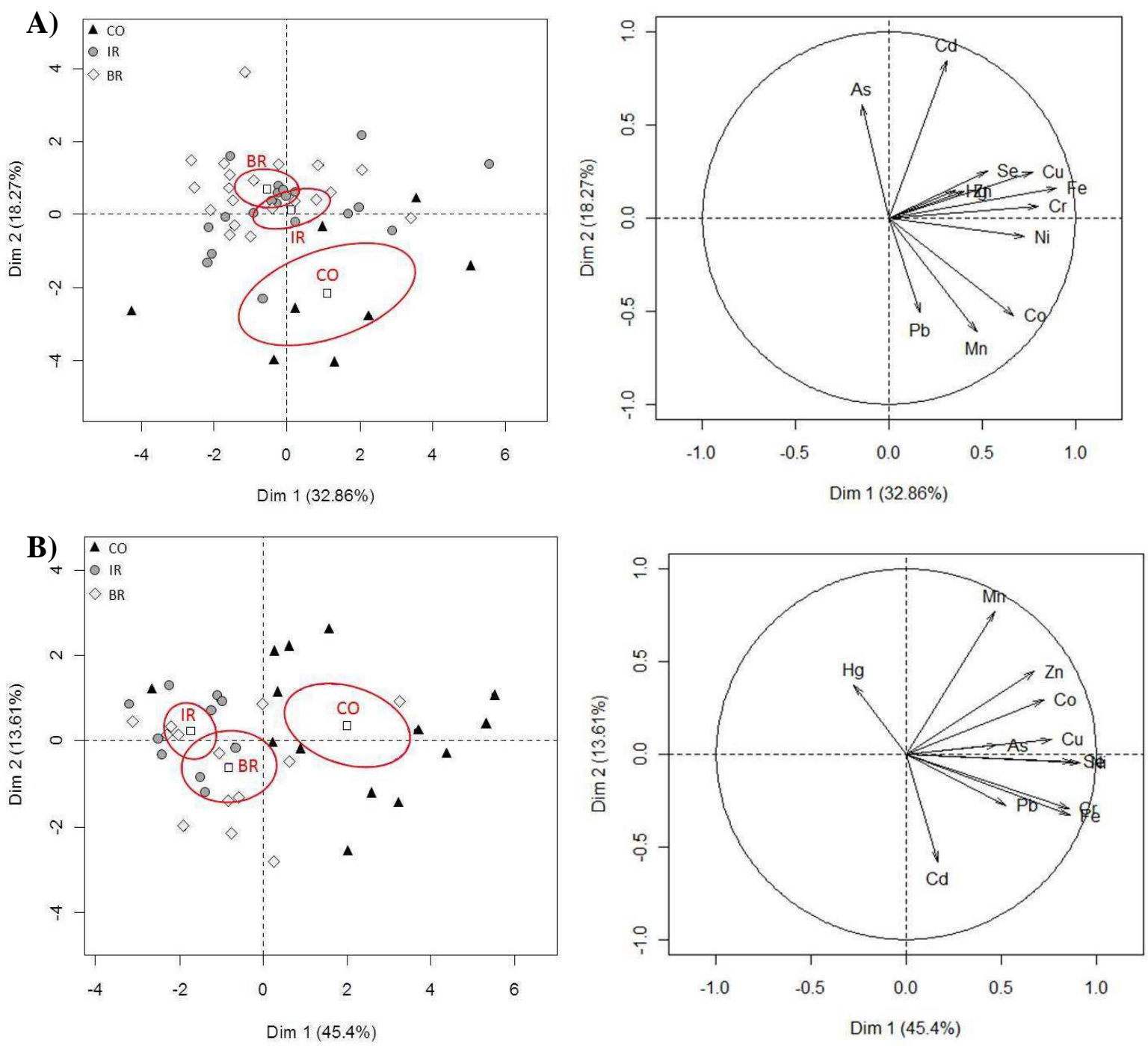

Figure 2. Plot of the principal component analysis (PCA) assessing spatial patterns of anguilliform fish contamination by trace elements on the coast-barrier reef gradient (left panel) and the contribution of the contaminants analyzed to site differentiation (right panel) in G. chilospilus (A) and Conger $\mathrm{sp}$. (B). $\mathrm{CO}=$ coastal sites; $\mathrm{IR}=$ intermediate reef sites; $\mathrm{BR}=$ barrier reef sites. The most contributing variables in both species were $\mathrm{Cr}, \mathrm{Cu}, \mathrm{Fe}, \mathrm{Ni}$ concentrations for the first axis and $\mathrm{Cd}$ and $\mathrm{Mn}$ concentrations for the second axis. The significant differences between sites are illustrated by confidence ellipses of centroids at $95 \%$. 
Table 1. Number (N) of fish analyzed from the coastal (CO), intermediate (IR) and barrier reef (BR) sites in Grand Nouméa (GN) and Grand Lagon Sud (GS). Mean ( \pm SD) fish total length (TL, cm), trophic position (express with $\delta^{15} \mathrm{~N}, \%$ ) and lipid content $(\mathrm{Lp}, \%)$ are given, with minimal and maximal values (min-max) indicated in brackets. No variation of TL, $\delta^{15} \mathrm{~N}$ and Lp between sites was observed ( $\mathrm{p}_{\text {ANOVA }}>0.05$ ).

\begin{tabular}{|c|c|c|c|c|c|c|c|}
\hline Species & Site & $\mathbf{N}$ & $\mathbf{N}(\mathbf{G N})$ & $\mathbf{N}(\mathbf{G S})$ & TL $(\mathrm{cm})(\min -\max )$ & $\delta^{15} \mathrm{~N}(\% 0)(\min -\max )$ & $\mathbf{L p}(\%)(\min -\mathbf{m a x})$ \\
\hline Gymnothorax & $\mathrm{CO}$ & 8 & 3 & 5 & $21.2 \pm 4.3(14.7-28.4)$ & $8.0 \pm 0.8(7.1-9.3)$ & $1.2 \pm 1.3(0.2-3.6)$ \\
\hline \multirow[t]{3}{*}{ chilospilus } & IR & 20 & 10 & 10 & $25.3 \pm 4.8(14.0-37.2)$ & $7.9 \pm 0.7(6.7-9.5)$ & $0.8 \pm 0.8(0.2-3.3)$ \\
\hline & BR & 20 & 10 & 10 & $25.1 \pm 2.3(21.4-30.8)$ & $7.8 \pm 0.5(7.1-8.8)$ & $0.7 \pm 0.6(0.2-1.8)$ \\
\hline & Total & 48 & 23 & 25 & $24.5 \pm 4.1(21.7-31.2)$ & $7.9 \pm 0.6(6.7-9.5)$ & $0.8 \pm 0.8(0.2-3.6)$ \\
\hline \multirow[t]{4}{*}{ Conger sp. } & $\mathrm{CO}$ & 14 & 9 & 5 & $29.0 \pm 4.6(23.2-38.3)$ & $8.6 \pm 1.4(6.6-10.5)$ & $1.0 \pm 0.7(0.2-1.9)$ \\
\hline & IR & 10 & 0 & 10 & $34.4 \pm 8.9(20.3-48.7)$ & $8.5 \pm 0.8(7.7-9.9)$ & $1.5 \pm 1.6(0.3-5.5)$ \\
\hline & $\mathrm{BR}$ & 13 & 8 & 5 & $35.7 \pm 6.3(27.7-51.7)$ & $8.5 \pm 0.9(7.1-10.3)$ & $1.0 \pm 1.2(0.3-3.6)$ \\
\hline & Total & 37 & 17 & 20 & $32.7 \pm 7.1(20.3-51.7)$ & $8.6 \pm 1.0(6.6-10.5)$ & $1.2 \pm 1.2(0.2-5.5)$ \\
\hline
\end{tabular}


Table 2. Trace element and organic pollutant concentrations (mean \pm SD and range of values; $\mu \mathrm{g} \cdot \mathrm{g}^{-1} \mathrm{dw}$ ) measured in muscle of G. chilospilus and Conger sp., all sites confounded.

\begin{tabular}{|c|c|c|c|}
\hline & & G. chilospilus & Conger sp. \\
\hline \multirow{12}{*}{ 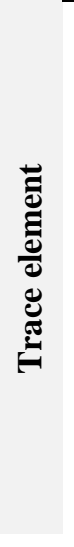 } & As & $11 \pm 7.4(0.9-31.9)$ & $25.7 \pm 25.6(3.0-117.9)$ \\
\hline & Cd & $0.41 \pm 0.47(0.01-2.91)$ & $0.04 \pm 0.04(0.01-0.16)$ \\
\hline & Co & $0.11 \pm 0.08(0.02-0.45)$ & $0.13 \pm 0.15(0.02-0.68)$ \\
\hline & $\mathrm{Cr}$ & $4.53 \pm 7.15(0.86-35.71)$ & $4.03 \pm 5.36(0.45-23.60)$ \\
\hline & $\mathrm{Cu}$ & $1.6 \pm 0.7(0.7-3.4)$ & $1.9 \pm 0.9(0.7-4.5)$ \\
\hline & $\mathbf{F e}$ & $40.2 \pm 36.9(12.2-196.8)$ & $34.3 \pm 31.1(7.9-134.4)$ \\
\hline & Hg & $0.049 \pm 0.028(0.02-0.13)$ & $0.117 \pm 0.112(0.03-0.6)$ \\
\hline & Mn & $2.3 \pm 1.4(0.6-7.2)$ & $2.7 \pm 2.3(0.4-10.1)$ \\
\hline & $\mathbf{N i}$ & $1.95 \pm 3.19(0.30-17.38)$ & $1.44 \pm 1.77(0.10-7.74)$ \\
\hline & $\mathbf{P b}$ & $0.05 \pm 0.04(0.01-0.2)$ & $0.04 \pm 0.09(12.2-196.8)$ \\
\hline & Se & $1.2 \pm 0.4(0.7-2.6)$ & $1.8 \pm 0.8(0.9-4.6)$ \\
\hline & $\mathbf{Z n}$ & $56.5 \pm 16.4(26.5-112.3)$ & $45.4 \pm 23.8(21.6-112.1)$ \\
\hline \multirow{13}{*}{ 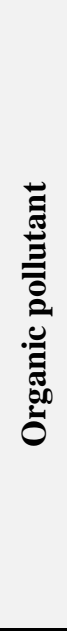 } & PCBTot & $59.1 \pm 52.7(9.3-271.5)$ & $63.2 \pm 54.8(9.1-211.4)$ \\
\hline & $\Sigma I C E S$ & $14.0 \pm 12.2(2.0-64.3)$ & $16.5 \pm 14.3(2.1-60.9)$ \\
\hline & Aldrin & $0.1 \pm 0.06(0.08-0.3)$ & $0.1 \pm 0.05(0.04-0.2)$ \\
\hline & Diazinon & $1.8 \pm 1.9(<0.1-10.2)$ & $2.4 \pm 3.3(<0.1-15.3)$ \\
\hline & Dieldrin & $0.4 \pm 0.3(<0.2-1.8)$ & $0.5 \pm 0.4(<0.2-2.2)$ \\
\hline & Endosulfan I & $1.3 \pm 1.3(<0.2-6.1)$ & $1.0 \pm 1.7(0.09-9.7)$ \\
\hline & Endosulfan II & $2.1 \pm 1.7(<0.1-7.3)$ & $2.9 \pm 2.3(<0.1-8.9)$ \\
\hline & Endrin & $0.3 \pm 0.8(<0.1-4.5)$ & $0.8 \pm 2.0(0.07-9.9)$ \\
\hline & Heptachlor & $0.4 \pm 0.4(<0.1-1.9)$ & $0.5 \pm 0.4(<0.1-1.9)$ \\
\hline & Heptachlor-epox.A & $1.5 \pm 1.2(0.03-5.6)$ & $1.8 \pm 1.9(0.1-9.1)$ \\
\hline & Heptachlor-epox.B & $0.3 \pm 0.5(<0.01-2.6)$ & $0.5 \pm 0.6(<0.01-2.7)$ \\
\hline & Lindane & $1.3 \pm 0.6(0.3-3.1)$ & $1.7 \pm 1.2(0.2-5.1)$ \\
\hline & $\Sigma D D T$ & $1.6 \pm 1.5(0.3-6.9)$ & $1.6 \pm 1.5(0.3-7.2)$ \\
\hline
\end{tabular}


Table 3. Trace element concentrations (mean (SD); $\mu \mathrm{g} . \mathrm{g}^{-1} \mathrm{dw}$ ) in G. chilospilus and Conger sp. along the coastal-barrier reef gradient. ANOVA (ANV) or ANCOVA (ACV) with Tukey's pairwise comparisons were used to analyze spatial patterns.

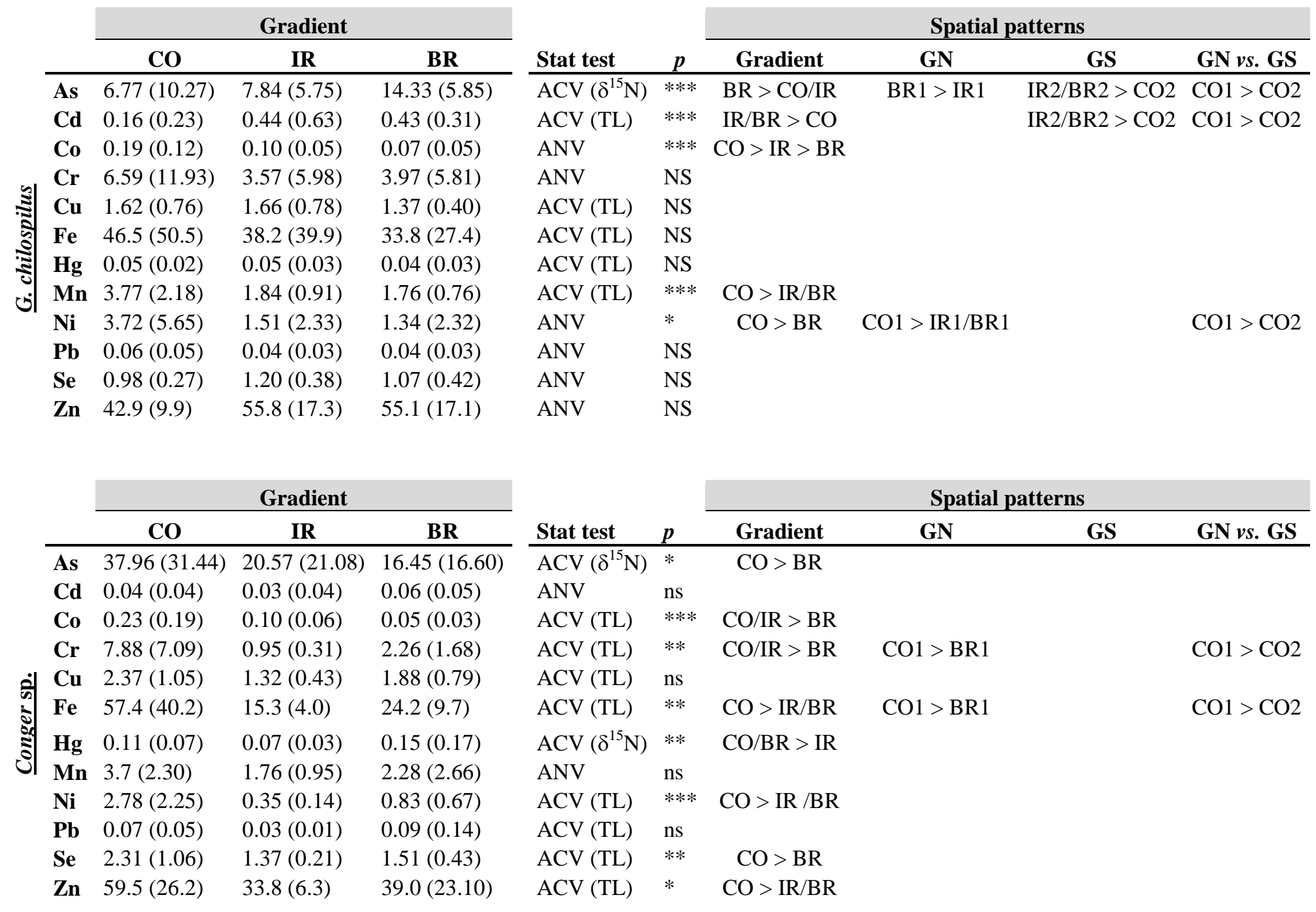

Note: GN: Grand Nouméa; GS: Grand Lagon Sud; CO: coastal sites; IR: intermediate reef sites; BR: barrier reef sites ns $=$ not significant $(\mathrm{p}>0.05) ; * \mathrm{p}<0.05, * * \mathrm{p}<0.01, * * * \mathrm{p}<0.001$ 
Table 4. PCBs and pesticide concentrations (mean (SD); ng. $\mathrm{g}^{-1} \mathrm{dw}$, except $\%$ of classes) in G. chilospilus (A) and Conger sp. (B) along the coastbarrier reef gradient. ANOVA or ANCOVA with Tukey's pairwise comparisons were used to analyze spatial patterns

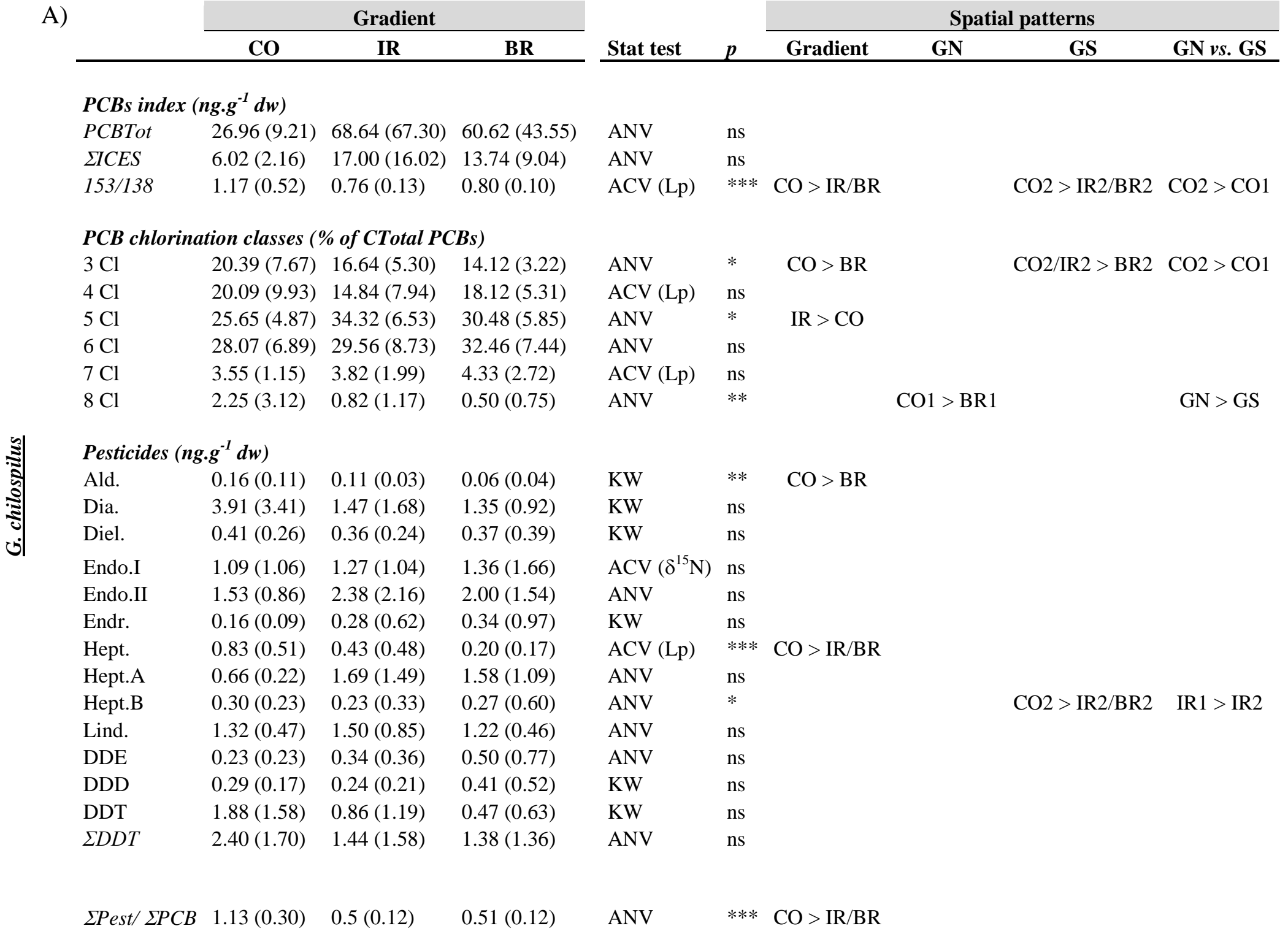




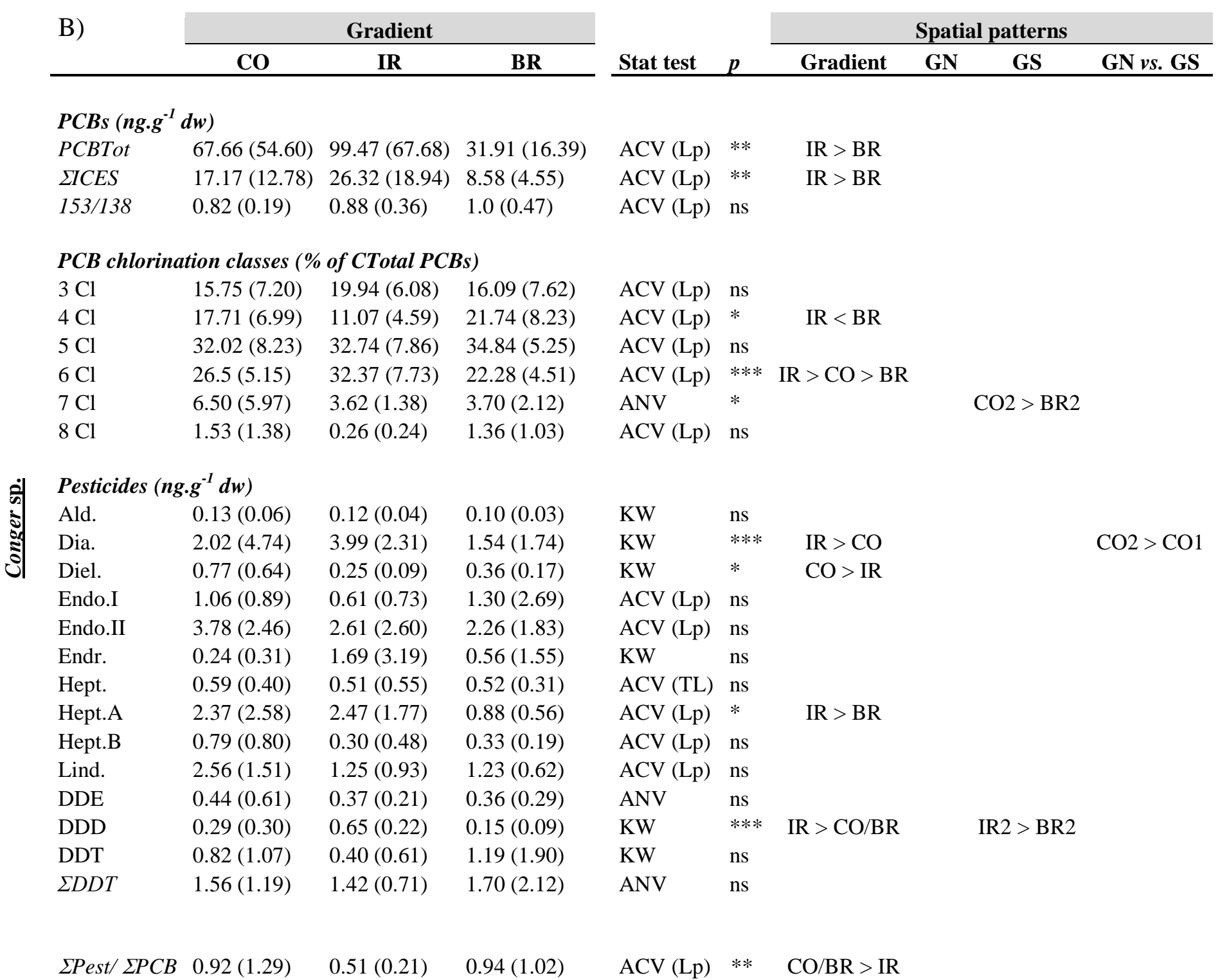

Note: GN: Grand Nouméa; GS: Grand Lagon Sud; CO: coastal sites; IR: intermediate reef sites; BR: barrier reef sites

$\mathrm{ns}=$ not significant $(\mathrm{p}>0.05) ; * \mathrm{p}<0.05, * * \mathrm{p}<0.01, * * * \mathrm{p}<0.001 /(+)$ positive and (-) negative correlation. ${ }^{\mathrm{a}}$ only one value. 
Table 5. Summary of correlations performed on trace elements and organic pollutants (PCBs and pesticides) concentrations versus total length (TL), trophic position $\left(\delta^{15} \mathrm{~N}\right)$ and lipid content (Lp) in G. chilospilus and Conger sp.

\begin{tabular}{|c|c|c|c|}
\hline & \multicolumn{3}{|c|}{ G. chilospilus } \\
\hline & Trace elements & PCBs & Pesticides \\
\hline $\mathrm{TL}$ & $\begin{array}{l}\underline{\mathrm{As}}^{*}, \underline{\mathrm{Cd}}^{* *}, \mathrm{Cu}^{*}, \mathrm{Fe}^{*}, \\
\mathrm{Mn}^{*}\end{array}$ & & Ald.**, Dia.** \\
\hline$\delta^{15} \mathrm{~N}$ & & & Endo. $*$ \\
\hline Lp & & $\underline{C B 153 / 138}^{* *}, \underline{4 \mathrm{Cl}}^{* *}, \underline{8 \mathrm{Cl}}^{*}$ & $\underline{\text { Hept. }} * *$ \\
\hline
\end{tabular}

\begin{tabular}{|c|c|c|c|}
\hline & \multicolumn{3}{|c|}{ Conger sp. } \\
\hline & Trace elements & PCBs & Pesticides \\
\hline $\mathrm{TL}$ & $\begin{array}{l}\mathrm{Co}^{* *}, \mathrm{Cr}^{*}, \mathrm{Cu}^{* *}, \mathrm{Fe}^{*}, \\
\mathrm{Ni}^{*}, \mathrm{~Pb}^{*}, \mathrm{Se}^{*}, \mathrm{Zn}^{*}\end{array}$ & & Hept.** \\
\hline$\delta^{15} \mathrm{~N}$ & $\underline{\mathrm{As}}^{* * *}, \underline{\mathrm{Hg}} * * *$ & & Ald $*$ \\
\hline $\mathrm{Lp}$ & & $\begin{array}{l}\frac{\text { CTotal PCBs }}{\text { CB153/138 }} *, \underline{\text { SICES }} *, \\
5 \mathrm{Cl}^{* *}, 6 \mathrm{Cl}^{*}, \underline{\mathrm{Cl}}^{*}, \underline{\mathrm{Cl}}^{* *}\end{array}$ & 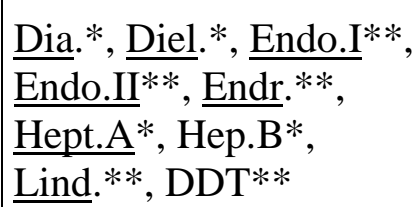 \\
\hline
\end{tabular}

Note: $3 \mathrm{Cl}$ to $8 \mathrm{Cl}$ : classes of chlorination; Lind.: Lindane; Dia.: Diazinon; Hept.: Heptachlor; Ald.: Aldrin; Hept.B: Heptachlor-epox.B; Hept.A: Heptachlor-epox.A; Endo.I: Endosulfan I; Diel: Dieldrin; Endr.; Endrin; DDT : pp'-DDT.

Significativity: $* \mathrm{p}<0.05, * * \mathrm{p}<0.01, * * * \mathrm{p}<0.001$.

Positive correlations are underlined. 
Table 6. Comparison of several trace element concentrations (mean \pm SD and range of values; $\mu \mathrm{g} . \mathrm{g}^{-1} \mathrm{dw}$ ) measured in muscle of $G$. chilospilus, Conger sp. and other lagoon fish species in New Caledonia.

\begin{tabular}{|c|c|c|c|}
\hline Trace element & Concentration $\left(\mu \mathrm{g} \cdot \mathrm{g}^{-1} \mathrm{dw}\right)$ & species & reference \\
\hline As & $11.0 \pm 7.4(0.9-31.9)$ & G. chilospilus & This study \\
\hline As & $25.7 \pm 25.6(3.0-117.9)$ & Conger sp. & This study \\
\hline As & $13.7 \pm 7.57(<7.87-19.1)$ & Lethrinus laticaudis & Metian et al. (2013) \\
\hline As & $9.47 \pm 1.47(<7.85-10.7)$ & Priacanthus hamrur & Metian et al. (2013) \\
\hline As & $<6.01-7.77$ & Cymbacephalus beauforti & Metian et al. (2013) \\
\hline As & $1.2-52.5$ & $\operatorname{mix}$ & Fernandez and Breau (2011) \\
\hline Cd & $0.41 \pm 0.47(0.01-2.91)$ & G. chilospilus & This study \\
\hline Cd & $0.04 \pm 0.04(0.01-0.16)$ & Conger sp. & This study \\
\hline $\mathrm{Cd}$ & $<0.06$ & $\operatorname{mix}$ & Fernandez and Breau (2011) \\
\hline Co & $0.11 \pm 0.08(0.02-0.45)$ & G. chilospilus & This study \\
\hline Co & $0.13 \pm 0.15(0.02-0.68)$ & Conger sp. & This study \\
\hline $\mathrm{Co}$ & $<0.03$ & Lethrinus laticaudis & Metian et al. (2013) \\
\hline Co & $<0.03$ & Priacanthus hamrur & Metian et al. (2013) \\
\hline $\mathrm{Co}$ & $<0.02$ & Cymbacephalus beauforti & Metian et al. (2013) \\
\hline $\mathrm{Co}$ & $<0.1-1.1$ & $\operatorname{mix}$ & Fernandez and Breau (2011) \\
\hline $\mathrm{Cr}$ & $4.53 \pm 7.15(0.86-35.71)$ & G. chilospilus & This study \\
\hline $\mathrm{Cr}$ & $4.03 \pm 5.36(0.45-23.60)$ & Conger sp. & This study \\
\hline $\mathrm{Cr}$ & $<0.79$ & Lethrinus laticaudis & Metian et al. (2013) \\
\hline $\mathrm{Cr}$ & $1.39(<0.70-1.39)$ & Priacanthus hamrur & Metian et al. (2013) \\
\hline $\mathrm{Cr}$ & $<0.60$ & Cymbacephalus beauforti & Metian et al. (2013) \\
\hline $\mathrm{Cr}$ & $<0.1-5.7$ & $\operatorname{mix}$ & Fernandez and Breau (2011) \\
\hline $\mathbf{C u}$ & $1.6 \pm 0.7(0.7-3.4)$ & G. chilospilus & This study \\
\hline $\mathbf{C u}$ & $1.9 \pm 0.9(0.7-4.5)$ & Conger sp. & This study \\
\hline $\mathrm{Cu}$ & $<0.79$ & Lethrinus laticaudis & Metian et al. (in press) \\
\hline $\mathrm{Cu}$ & $<0.83$ & Priacanthus hamrur & Metian et al. (in press) \\
\hline $\mathrm{Cu}$ & $<0.53-0.64$ & Cymbacephalus beauforti & Metian et al. (in press) \\
\hline $\mathrm{Cu}$ & $0.25-3.0$ & $\operatorname{mix}$ & Fernandez and Breau (2011) \\
\hline $\mathbf{F e}$ & $40.2 \pm 36.9(12.2-196.8)$ & G. chilospilus & This study \\
\hline $\mathbf{F e}$ & $34.3 \pm 31.1(7.9-134.4)$ & Conger sp. & This study \\
\hline $\mathrm{Fe}$ & $9.19 \pm 1.42(7.56-10.1)$ & Lethrinus laticaudis & Metian et al. (2013) \\
\hline $\mathrm{Fe}$ & $10.4 \pm 3.56(7.82-16.9)$ & Priacanthus hamrur & Metian et al. (2013) \\
\hline $\mathrm{Fe}$ & $7.01-7.60$ & Cymbacephalus beauforti & Metian et al. (2013) \\
\hline $\mathrm{Fe}$ & $4.0-211$ & $\operatorname{mix}$ & Fernandez and Breau (2011) \\
\hline Mn & $2.3 \pm 1.4(0.6-7.2)$ & G. chilospilus & This study \\
\hline Mn & $2.7 \pm 2.3(0.4-10.1)$ & Conger sp. & This study \\
\hline $\mathrm{Mn}$ & $<0.79$ & Lethrinus laticaudis & Metian et al. (2013) \\
\hline $\mathrm{Mn}$ & $<0.83$ & Priacanthus hamrur & Metian et al. (2013) \\
\hline Mn & $<0.60$ & Cymbacephalus beauforti & Metian et al. (2013) \\
\hline $\mathrm{Mn}$ & $<0.03-3.3$ & $\operatorname{mix}$ & Fernandez and Breau (2011) \\
\hline $\mathbf{N i}$ & $1.95 \pm 3.19(0.30-17.38)$ & G. chilospilus & This study \\
\hline $\mathbf{N i}$ & $1.44 \pm 1.77(0.10-7.74)$ & Conger sp. & This study \\
\hline $\mathrm{Ni}$ & $<0.06-1.35$ & $\operatorname{mix}$ & Fernandez and Breau (2011) \\
\hline
\end{tabular}

Note: $\operatorname{mix}=144$ fish from 27 species and 10 families (Acanthuridae, Carangidae, Haemulidae, Labridae, Lethrinidae, Lutjanidae, Mugilidae, Scaridae, Serranidae and Siganidae). 
Table S1. Trace element concentrations (mean (SD); $\mu \mathrm{g} \cdot \mathrm{g}^{-1} \mathrm{dw}$ ) in G. chilospilus and Conger sp. along the gradient in Grand Nouméa and Grand Lagon Sud.

\begin{tabular}{|c|c|c|c|}
\hline & \multicolumn{3}{|c|}{ Grand Nouméa (GN) } \\
\hline & CO1 & IR1 & BR1 \\
\hline As & $16.27(13.65)$ & $8.57(7.52)$ & $16.75(4.87)$ \\
\hline Cd & $0.36(0.31)$ & $0.36(0.30)$ & $0.36(0.18)$ \\
\hline Co & $0.21(0.10)$ & $0.10(0.05)$ & $0.09(0.06)$ \\
\hline $\mathrm{Cr}$ & $16.83(16.87)$ & $3.21(2.04)$ & $4.28(3.30)$ \\
\hline $\mathrm{Cu}$ & $2.35(0.85)$ & $1.75(0.89)$ & $1.38(0.30)$ \\
\hline $\mathbf{F e}$ & $95.2(64.4)$ & $33.8(19.0)$ & $35.4(15.7)$ \\
\hline $\mathrm{Hg}$ & $0.07(0.03)$ & $0.05(0.02)$ & $0.04(0.02)$ \\
\hline Mn & $2.92(0.89)$ & $2.13(1.18)$ & $1.70(0.43)$ \\
\hline $\mathrm{Ni}$ & $9.21(7.09)$ & $1.33(0.79)$ & $1.09(0.81)$ \\
\hline $\mathbf{P b}$ & $0.07(0.03)$ & $0.06(0.07)$ & $0.05(0.04)$ \\
\hline $\mathbf{S e}$ & $1.17(0.28)$ & $1.21(0.47)$ & $1.00(0.19)$ \\
\hline $\mathbf{Z n}$ & $50.2(6.5)$ & $59.9(23.3)$ & $52.7(11.4)$ \\
\hline
\end{tabular}

\begin{tabular}{ccc}
\multicolumn{3}{c}{ Grand Lagon Sud (GS) } \\
\hline CO2 & IR2 & \multicolumn{1}{c}{ BR2 } \\
\hline $2.42(1.26)$ & $7.90(3.62)$ & $13.34(6.49)$ \\
$0.06(0.07)$ & $0.56(0.85)$ & $0.54(0.34)$ \\
$0.22(0.14)$ & $0.11(0.06)$ & $0.05(0.03)$ \\
$1.76(0.74)$ & $4.28(8.41)$ & $4.05(7.77)$ \\
$1.51(0.57)$ & $1.74(0.69)$ & $1.49(0.50)$ \\
$26.5(13.0)$ & $46.4(54.0)$ & $35.5(36.6)$ \\
$0.05(0.04)$ & $0.07(0.04)$ & $0.04(0.02)$ \\
$5.04(2.41)$ & $1.72(0.51)$ & $2.00(0.98)$ \\
$1.17(0.76)$ & $1.84(3.27)$ & $1.73(3.23)$ \\
$0.06(0.03)$ & $0.03(0.03)$ & $0.04(0.03)$ \\
$1.07(0.28)$ & $1.31(0.28)$ & $1.25(0.54)$ \\
$47.0(12.1)$ & $57.3(9.3)$ & $63.0(20.7)$
\end{tabular}

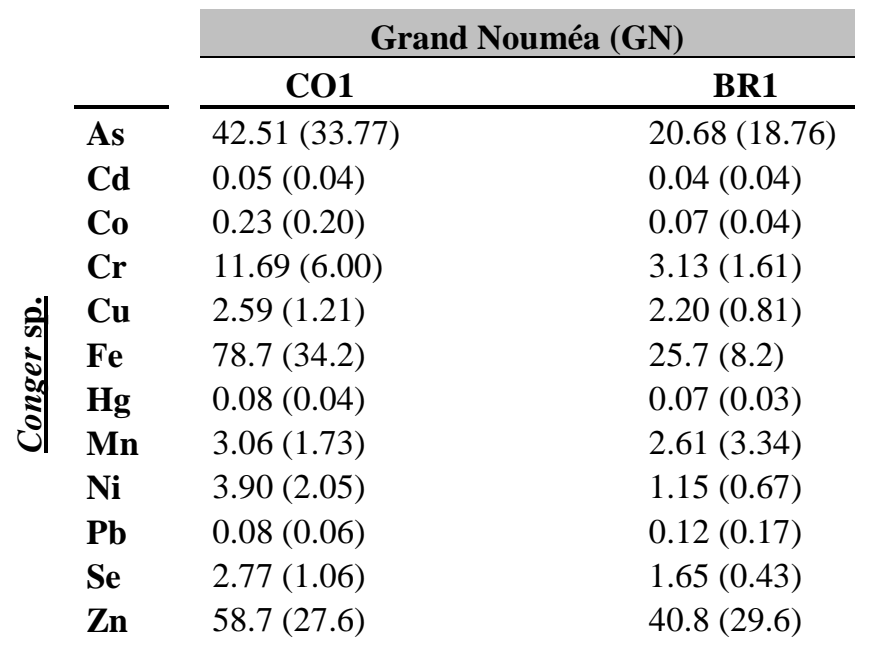

\begin{tabular}{lll}
\multicolumn{3}{c}{ Grand Lagon Sud (GS) } \\
\hline \multicolumn{1}{c}{ CO2 } & \multicolumn{1}{c}{ IR2 } & \multicolumn{1}{c}{ BR2 } \\
\hline $29.77(28.29)$ & $20.57(21.08)$ & $9.67(10.84)$ \\
$0.02(0.01)$ & $0.03(0.04)$ & $0.08(0.07)$ \\
$0.23(0.21)$ & $0.10(0.06)$ & $0.03(0.01)$ \\
$1.02(0.45)$ & $0.95(0.31)$ & $0.86(0.14)$ \\
$1.98(0.61)$ & $1.32(0.43)$ & $1.42(0.55)$ \\
$19.1(7.60)$ & $15.3(4.0)$ & $21.6(12.3)$ \\
$0.18(0.09)$ & $0.07(0.03)$ & $0.28(0.22)$ \\
$4.86(2.93)$ & $1.76(0.95)$ & $1.74(1.06)$ \\
$0.77(0.25)$ & $0.35(0.14)$ & $0.32(0.20)$ \\
$0.06(0.02)$ & $0.03(0.01)$ & $0.03(0.01)$ \\
$1.50(0.28)$ & $1.37(0.21)$ & $1.28(0.34)$ \\
$60.9(26.5)$ & $33.8(6.3)$ & $36.2(6.9)$
\end{tabular}

Note: CO: coastal sites; IR: intermediate reef sites; BR: barrier reef sites. 
Table S2. Trace element concentrations (mean (SD); $\mu \mathrm{g} \cdot \mathrm{g}^{-1} \mathrm{dw}$ ) in G. chilospilus (A) and Conger sp. (B) along the gradient in Grand Nouméa and Grand Lagon Sud.

\begin{tabular}{|c|c|c|c|c|c|c|}
\hline \multirow[t]{2}{*}{ A) } & \multicolumn{3}{|c|}{ Grand Nouméa (GN) } & \multicolumn{3}{|c|}{ Grand Lagon Sud (GS) } \\
\hline & CO1 & IR1 & BR1 & $\mathrm{CO} 2$ & IR2 & BR2 \\
\hline \multicolumn{7}{|c|}{ PCBs index (ng.g $\left.g^{-1} d w\right)$} \\
\hline PCBTot & $25.79(8.98)$ & 70.14 (78.71) & $59.07(56.06)$ & $28.13(11.28)$ & $66.95(57.15)$ & $62.18(29.27)$ \\
\hline IICES & $5.80(1.67)$ & $17.59(18.5)$ & $13.65(11.80)$ & $6.25(2.90)$ & $16.33(13.90)$ & $13.83(5.80)$ \\
\hline $153 / 138$ & $0.71(0.10)$ & $0.75(0.15)$ & $0.78(0.08)$ & $1.62(0.20)$ & $0.77(0.13)$ & $0.82(0.11)$ \\
\hline \multicolumn{7}{|c|}{ PCB chlorination classes (\% of CTotal PCBs) } \\
\hline $3 \mathrm{Cl}$ & $14.34(4.50)$ & $14.09(4.40)$ & $14.51(4.11)$ & $26.44(4.10)$ & $19.51(4.90)$ & $13.74(2.16)$ \\
\hline $4 \mathrm{Cl}$ & $24.48(12.55)$ & $16.06(10.80)$ & $18.52(7.00)$ & $15.71(5.60)$ & $13.47(2.70)$ & $17.71(3.19)$ \\
\hline $5 \mathrm{Cl}$ & $24.42(5.30)$ & $33.18(7.50)$ & $30.82(4.90)$ & $26.87(5.20)$ & $35.60(5.40)$ & $30.14(6.92)$ \\
\hline $6 \mathrm{Cl}$ & $28.72(10.30)$ & $30.73(11.20)$ & $30.32(7.60)$ & $27.42(3.40)$ & $28.24(5.20)$ & $34.59(7.04)$ \\
\hline $7 \mathrm{Cl}$ & $3.64(1.58)$ & $4.67(2.30)$ & $5.02(3.50)$ & $3.46(0.89)$ & $2.87(0.88)$ & $3.64(1.44)$ \\
\hline $8 \mathrm{Cl}$ & $4.40(3.25)$ & $1.27(1.50)$ & $0.81(0.98)$ & $0.11(0.05)$ & $0.31(0.36)$ & $0.18(0.14)$ \\
\hline \multicolumn{7}{|c|}{ Pesticides $\left(n g . g^{-1} d w\right)$} \\
\hline Ald. & $0.11(0.03)$ & $0.11(0.03)$ & $0.07(0.04)$ & $0.21(0.15)$ & $0.12(0.04)$ & $0.06(0.04)$ \\
\hline Dia. & $5.18(4.63)$ & $1.72(2.30)$ & $1.08(1.00)$ & $2.64(1.70)$ & $1.20(0.67)$ & $1.63(0.78)$ \\
\hline Diel. & $0.30(0.17)$ & $0.43(0.28)$ & $0.44(0.50)$ & $0.51(0.33)$ & $0.28(0.16)$ & $0.29(0.23)$ \\
\hline Endo.I & $0.83(0.58)$ & $0.95(0.87)$ & $1.17(1.80)$ & $1.35(1.50)$ & $1.64(1.10)$ & $1.56(1.60)$ \\
\hline Endo.II & $1.30(0.09)$ & $2.73(2.10)$ & $1.87(1.60)$ & $1.77(1.30)$ & $1.99(2.30)$ & $2.12(1.60)$ \\
\hline Endr. & $0.18(0.13)$ & $0.43(0.85)$ & $0.13(0.06)$ & $0.13(0.05)$ & $0.10(0.01)$ & $0.55(1.40)$ \\
\hline Hept. & $0.47(0.17)$ & $0.59(0.57)$ & $0.23(0.17)$ & $1.18(0.49)$ & $0.25(0.28)$ & $0.18(0.18)$ \\
\hline Hept.A & $0.59(0.15)$ & $1.66(1.40)$ & $1.46(1.20)$ & $0.73(0.29)$ & $1.73(1.70)$ & $1.71(1.00)$ \\
\hline Hept.B & $0.20(0.16)$ & $0.40(0.39)$ & $0.41(0.78)$ & $0.40(0.27)$ & $0.04(0.03)$ & $0.13(0.32)$ \\
\hline Lind. & $1.49(0.51)$ & $1.72(0.91)$ & $1.28(0.58)$ & $1.15(0.46)$ & $1.26(0.77)$ & $1.16(0.32)$ \\
\hline DDE & $0.35(0.29)$ & $0.45(0.45)$ & $0.68(1.00)$ & $0.11(0.01)$ & $0.22(0.20)$ & $0.33(0.35)$ \\
\hline DDD & $0.29(0.18)$ & $0.28(0.29)$ & $0.50(0.72)$ & $0.29(0.21)$ & $0.19(0.05)$ & $0.31(0.19)$ \\
\hline DDT & $3.10(1.21)$ & $0.94(1.50)$ & $0.52(0.74)$ & $0.65(0.50)$ & $0.77(0.73)$ & $0.42(0.54)$ \\
\hline$\Sigma D D T$ & $3.74(1.31)$ & $1.67(2.00)$ & $1.71(1.80)$ & $1.05(0.31)$ & $1.18(0.90)$ & $1.06(0.55)$ \\
\hline $\begin{array}{l}\text { EPest/ } \\
\Sigma P C B\end{array}$ & $1.27(0.28)$ & $0.53(0.12)$ & $0.52(0.14)$ & $0.99(0.31)$ & $0.47(0.11)$ & $0.51(0.10)$ \\
\hline
\end{tabular}




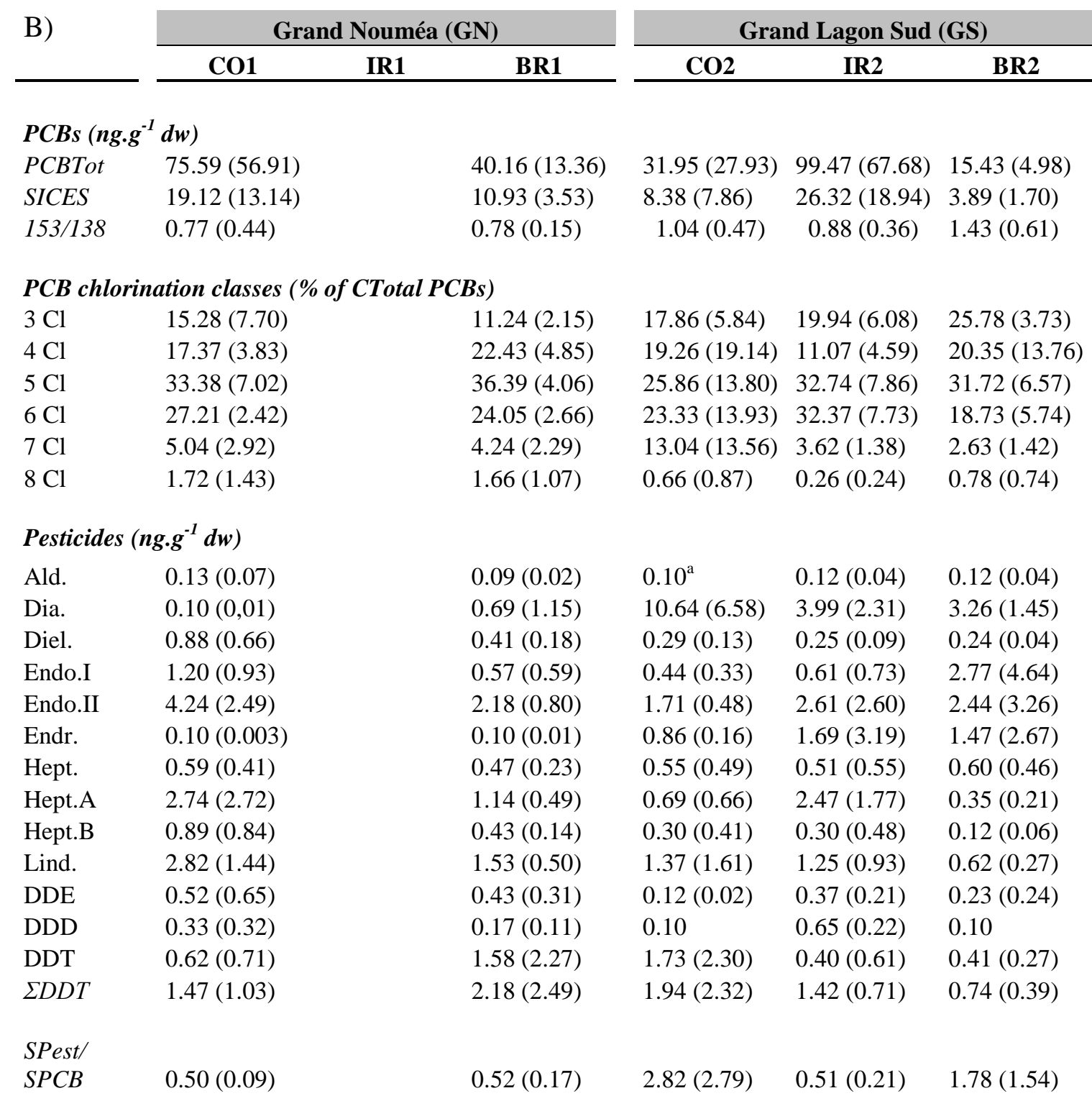

Note: CO: coastal sites; IR: intermediate reef sites; BR: barrier reef sites. ${ }^{a}$ only one value. 